OPEN ACCESS

Edited by:

Prateep Kumar Nayak,

University of Waterloo, Canada

Reviewed by:

Elizabeth Ingrid Van Putten,

Commonwealth Scientific and Industrial Research Organisation

(CSIRO), Australia

Helen Ross,

The University of Queensland,

Australia

*Correspondence:

María Garteizgogeascoa

garteizg@uni-bremen.de

TORCID:

María Garteizgogeascoa

0000-0001-8357-4357

Lotta C. Kluger

0000-0003-1433-4477

Gerardo Damonte

0000-0002-0529-2124

Michael Flitner

0000-0003-2179-8659

Specialty section:

This article was submitted to

Marine Conservation

and Sustainability,

a section of the journal

Frontiers in Marine Science

Received: 29 April 2020

Accepted: 28 September 2020

Published: 21 October 2020

Citation:

Garteizgogeascoa M, Kluger LC Gonzales IE, Damonte $G$ and Flitner M (2020) Contextualizing

Scenarios to Explore

Social-Ecological Futures: A Three

Step Participatory Case Study

for the Humboldt Current Upwelling

System. Front. Mar. Sci. 7:557181.

doi: 10.3389/fmars.2020.557181

\section{Contextualizing Scenarios to Explore Social-Ecological Futures: A Three Step Participatory Case Study for the Humboldt Current Upwelling System}

\author{
María Garteizgogeascoa ${ }^{1 * t}$, Lotta C. Kluger ${ }^{1,2 t}$, Isabel E. Gonzales ${ }^{3,4}$, \\ Gerardo Damonte ${ }^{3,4+}$ and Michael Flitner ${ }^{1,5+}$ \\ ${ }^{1}$ Artec Sustainability Research Center, Universität Bremen, Bremen, Germany, ${ }^{2}$ Leibniz Center for Tropical Marine Research, \\ Bremen, Germany, ${ }^{3}$ Grupo de Análisis para el Desarrollo, Lima, Peru, ${ }^{4}$ Department of Social Sciences, Catholic University \\ of Peru, Lima, Peru, ${ }^{5}$ Institute of Geography, Universität Bremen, Bremen, Germany
}

In the face of global change, the exploration of possible futures of marine socialecological systems (MSES) becomes increasingly important. A variety of models aims at improving our understanding of ecosystem dynamics and complexities by assessing how systems react to internal and external drivers of change. However, these models are often built from a natural-science perspective through a reductionist and top-down knowledge production process that does not engage with the interests, concerns and knowledge of stakeholders. Our work explores different futures of the Peruvian MSES tied to the Humboldt Current Upwelling System (HCUS) through a sequential integrative participatory scenario process. The methodology used opens novel ways to explore, at different contextual levels, the uncertainties of the future and, in doing so, to include diverging world views of different actors. This approach implies a broader social processing of scientific projections about the future and encourages the articulation of different notions of sustainability. We thereby contribute to current scientific discussions on scenario planning in MSES by exploring potential futures through the analysis of narratives, a process that helps to identify plausible future development pathways that can inform different types of ecosystem modeling or policy making.

Keywords: transdisciplinary methods, sustainability, scenarios, fisheries, Humboldt Current Upwelling System

\section{INTRODUCTION}

In a world of rapid global change and multiple anthropogenic pressures affecting socialecological systems (SES) in many dimensions, looking into the future becomes critical. Necessary transformations toward a more sustainable society are confronted with deep-seated uncertainties regarding economic, environmental, social and technical developments that will affect society and its natural environment in the coming decades (Priess et al., 2018). In the context of climate change, a particular focus is directed to the mitigation and adaptation capacities of communities to ensure viable policies, robustness of planning and political legitimacy (Larsen and Gunnarsson-Östling, 2009; McNamara and Buggy, 2017).

Scenario development has long been identified as a tool to tackle this multi-faceted task and explore the possible futures and associated impacts of SES (Börjeson et al., 2006; Kebede et al., 2018). 
Developing future scenarios to understand risks and uncertainties, has been part of the framework of "futurology" since the 1970s, with the Club of Rome's report on "The Limits to Growth" (Meadows et al., 1972) as its preeminent example. Thenceforth, future studies have moved forward and both methods and theories have multiplied, being summarized in several works (Oteros-Rozas et al., 2015; Minkkinen, 2020). Scenario development has become a common tool in global environmental assessments (Millennium Ecosystem Assessment [MA], 2005; Intergovernmental Science-Policy Platform on Biodiversity and Ecosystem Services [IPBES], 2015) and has been used widely in environmental and climate change studies over the last decades (Priess et al., 2018) mainly driven by the use of scenarios by the Intergovernmental Panel on Climate Change (IPCC). Today, scenarios are globally used as a key method for identifying plausible futures with medium- and long-term horizons (Saito et al., 2019) and stimulating reflective processes that can contribute to decision-making (Pereira et al., 2019).

Notwithstanding this renewed interest in scenario development, the theoretical foundations of future studies more broadly remain disputed. It is hardly surprising that a future which is conceived as being open to some extent leads to uncertainties and discussions when it comes to robust and reliable methodologies to explore this openness. Yet there are a number of widely shared practices and several plausible attempts to structure the field in theoretical terms, according to different criteria and multiple purposes (Minkkinen, 2020).

In an environmental sciences context, the appeal of quantitative approaches, forecasting, mathematical calculation and modeling is strong. Such probabilistic approaches, however, have great difficulties to integrate uncertainties that have not been measured with precision or consistency or are inherently difficult to quantify (deep uncertainties); and to capture contextspecific problems like socio-economic and cultural dynamics entangled with complex processes of meaning-making and normative symbolic orders. These phenomena are commonplace in the social-ecological field, and therefore the use of scenarios has moved toward an integrated analysis of both, environmental and socio-economic change, with a growing complexity in recent years (Kebede et al., 2018). The latest IPCC report (IPCC AR5), for example, considers climate, socio-economic and policy dimension of changes with its scenario framework combining greenhouse gas concentration pathways, socio-economic trajectories and shared policy assumptions (Intergovernmental Panel on Climate Change [IPCC], 2014).

In methodological terms, this growing complexity and need for integration has led to approaches that bring quantitative methods together with qualitative, interpretive and participatory methods (Rosenberg et al., 2014) that try to account for the knowledge, values, and experiences of different types of stakeholders and experts (Alcamo, 2001; Biggs et al., 2007; Butler et al., 2014; Hemmerling et al., 2019). According to Badjeck et al. (2011), thinking about the future through qualitative (or combined) scenarios can follow three basic modes: (1) predictive, in which actors aim to find the most likely development in the future usually based on present trends; (2) normative, focusing on desirable futures and possible paths that could lead to obtaining those goals; and (3) explorative, characterized by being open ("what could the future be?"), allowing to deal with high levels of uncertainty and ambiguity and encouraging creative thinking (cf. Pereira et al., 2019).

In this paper, we make use of exploratory scenarios, largely based on qualitative research. Hence, in line with many other authors, we do not aim at forecasts or predictions, but see scenarios rather as plausible descriptions of how the future might unfold, based on a coherent and internally consistent set of assumptions about key uncertainties and drivers of change (Millennium Ecosystem Assessment [MA], 2005; Palomo et al., 2011; Hamann et al., 2012; Kebede et al., 2018; Saito et al., 2019). Scenario construction in this sense is based on the premise that the future cannot be predicted but rather shaped (Venturini et al., 2019) and that the exploration about what could happen might be a useful "rehearsal" for the future.

As documented by Oteros-Rozas et al. (2015), the scenario making exercise typically involves the development of three to five scenarios each one shaped by a different constellation of drivers of changes identified through participatory methods and ranked based on their impact, probability of influence, importance and/or relevance for a given SES. Each scenario is at the end a reasonably coherent narrative about how the future might unfold in a given constellation of drivers. This narrative is generally constructed by a group of actors sharing experiences and insights in a creative and collaborative way, bringing in different perspectives and aspirations. Narratives in this sense are not the grand discourses of environmental governance or the paradigmatic "story lines" (Hajer, 1995) of ecological modernization. They are meaningful ways to assemble assumptions about social-ecological trajectories, to make sense of experiences and connect them to possible futures, by a person or a certain group of people. As such, they are bound to subjective, collective and cultural positions and processes (Wollenberg et al., 2000); they are of course imbued with larger questions of power (Nilsson et al., 2017) and, as a result, there will always be "competing narratives of sustainability" (Bremer and Funtowicz, 2015). For these reasons, the use of participatory methods and a local embedding of scenario processes are very relevant.

This task brings up two further questions: how to downscale, and how to integrate different types of knowledge. Traditionally, regional and local information has been obtained through the downscaling of global or national scenarios to smaller scales (Kebede et al., 2018; Ford et al., 2019; Karner et al., 2019; Kok et al., 2019; Mitter et al., 2019). However, Kok et al. (2019) have criticized that most attempts do not go beyond a case study implementation to test conceptual recommendations across complex systems, scales, and scenarios. Moreover, although downscaling is said to facilitate comparability between different case studies (Ebi et al., 2014), attempts to adapt global narratives of change to fit local contexts can be problematic in several respect. First, in spatial terms, global models tend to produce (world) subregions that are still far apart from the differences in everyday perceptions and experiences in terms of natural resource use, let alone patterns of the socio-political and cultural fabric. Second, for the purposes of community members or policy makers alike, global scenarios usually perform on large 
temporal scales (e.g., 50 or 100 years into the future). Hence assumptions become broader and simpler and results are more generalized which can make them useless, or at least meaningless in practical terms (Kebede et al., 2018). Finally, and this brings us to our second question, using IPCC's or other global sciencebased scenarios as a guiding framework can be seen as a restricted approach as these scenarios all have been constructed according to the principles of one and the same system of knowledge production, namely "modern," "Western" science, a positivistic endeavor, socially inert and politically neutral in its self-understanding, but rather narrow-minded, hegemonic and made of "farfetched facts" (Rottenburg, 2009) in the view of its contenders.

Against this background, several scholars have highlighted the need to develop methodologies that allow communities to frame their own visions of the future and (co-)produce regionally and locally relevant information (Saito et al., 2019). Locally based future visions are specially needed to include "traditional ecological knowledge" (Oteros-Rozas et al., 2015) or "indigenous knowledge" (Agrawal, 1995). Furthermore, we note that there is a growing interest also in social-ecological research to develop new modes of knowledge collaboration and "co-creation processes" in the context of future scenarios (Galafassi et al., 2018; Obermeister, 2019).

These developments in the broader debate on social-ecological scenarios are becoming visible in the field of MSES. Traditionally, the focus of scenarios for MSES has been on the analysis of single drivers of changes like coastal planning under climate change (Tompkins et al., 2008), commercial species or the increased demand for fish (Cheung et al., 2011; Béné et al., 2015). Only few studies have attempted to explore several drivers simultaneously, e.g., the work of Maury et al. (2017) in which they used scenario development to explore the future of the tuna fisheries along economic, fisheries management and global governance perspectives. Moreover, bigger projects such as Radical Ocean Futures aiming at imagining the potential future of the oceans through scientifically grounded science fiction narratives also lack contextualization (Pereira et al., 2019).

In this study, we first present a methodology (see section "Materials and Methods") that despite having its starting point in common methods of scenario making (i.e., axis technique) allows for a contextualization of uncertainties and for the integration of different knowledge systems and notions about the future (see section "Discussion"). We illustrate the methods with an application to the Humboldt Current Upwelling System (HCUS) of Peru. To the best of our knowledge, this is the first attempt of future studies in Peruvian MSES despite the increasing attention that future studies have had in Peru over the last decade (Instituto Nacional de Recursos Naturales [INRENA], 2008; Centro Nacional de Planeamiento Estratégico [Ceplan], 2014, 2019; Evans et al., 2014; Blancas et al., 2018). Given the great significance of fisheries in the country in social and economic terms and the ongoing changes in the Humboldt Current Upwelling System (see section "A descriptive Case Study: The Northern Humboldt Current Upwelling System”), integrative scenario development seems a fruitful endeavor. Therefore, our declared aim was to develop explorative scenarios, constructing narratives that deepen the understanding of the dynamics shaping the Humboldt Current Upwelling System, and also to refine and enrich the general visions on a regional scale. In section "Results" we present four collaboratively built narratives about trajectories of change over a 20 -year period and their contextualization in regional settings. A further aim was to provide a collaborative space for co-learning and strengthening links among and between researchers, policy makers and users.

\section{A DESCRIPTIVE CASE STUDY: THE NORTHERN HUMBOLDT CURRENT UPWELLING SYSTEM}

The Humboldt Current Upwelling System (HCUS), stretching from southern Chile to northern Peru, is one of the world's most productive marine ecosystems. This high productivity is created by coastal upwelling, transporting cold, nutrient-rich waters from deeper layer to the ocean's surface providing the basis for a high primary and fishery productivity. With an average annual capture production of $6,4 \times 10^{6}$ tons (for the period 2005-2014), Peru ranks as the second most important fisheries producer worldwide (after China), mainly due to the landings of the Peruvian anchovy Engraulis ringens, which represents $85 \%$ of annual catches (Food and Agriculture Organization of the United Nations [FAO], 2018). The fisheries sector represents Peru's second important sector after mining, contributing between 0.7 and $1.5 \%$ to the country's GDP [for the period 2008-2017. Note that the fishing sector as an economic sector within the national GDP, only corresponds to the extraction phase; the transformation (i.e., manufacture of fishmeal and fish oil, fish processing and preservation) is included in the manufacturing sector; Ministerio de la Producción [PRODUCE], 2018]. Targeting more than 300 species (Guevara-Carrasco and Bertrand, 2017), Peruvian small-scale fisheries (SSF) landings represent only about 9\% of the national total (Mendo and Wosnitza-Mendo, 2014), though the sector provides the majority of fish for domestic human consumption (26\% of animal protein; Béné, 2006) and employs four times more people than the industrial fisheries (Alvarez, 2003).

In the region Ica in the south of Peru (see Figure $\mathbf{1}^{1}$ ), both industrial and small-scale ${ }^{2}$ fisheries represent important oceanbased livelihoods, with Pisco ranking third when it comes to landings of the Peruvian anchoveta (Engraulis ringens) for fish meal and oil production, as well as for overall landings (in 2017; Ministerio de la Producción [PRODUCE], 2018, p. 57). Other important fisheries target species include the Eastern pacific

\footnotetext{
${ }^{1}$ Figure 1 was constructed in the $\mathrm{R}$ environment [ $\mathrm{R}$ Core Team, 2019 the maps (Brownrigg, 2018), sp. (Pebesma and Bivand, 2005; Bivand et al., 2013), sf (Pebesma, 2018)]. Peruvian administrative areas (region- and province-level) were retrieved from the Database of Global Administrative Areas (GADM, www.gadm.org, subdivision levels 1 and 2). National Reserve geographic information used for the figure was downloaded from the webpage of the Peruvian National Service for Natural Protected Areas (http://geo.sernanp.gob.pe/ visorsernanp/)

${ }^{2}$ Regulated by the D.S. $\mathrm{N}^{\circ}$ 005-2017-PRODUCE, the Peruvian law considers "small-scale" all vessels with a Gross Registered Tonnage up to $32.6 \mathrm{~m}^{3}$ and $15 \mathrm{~m}$ in length, while being operated predominantly manually.
} 


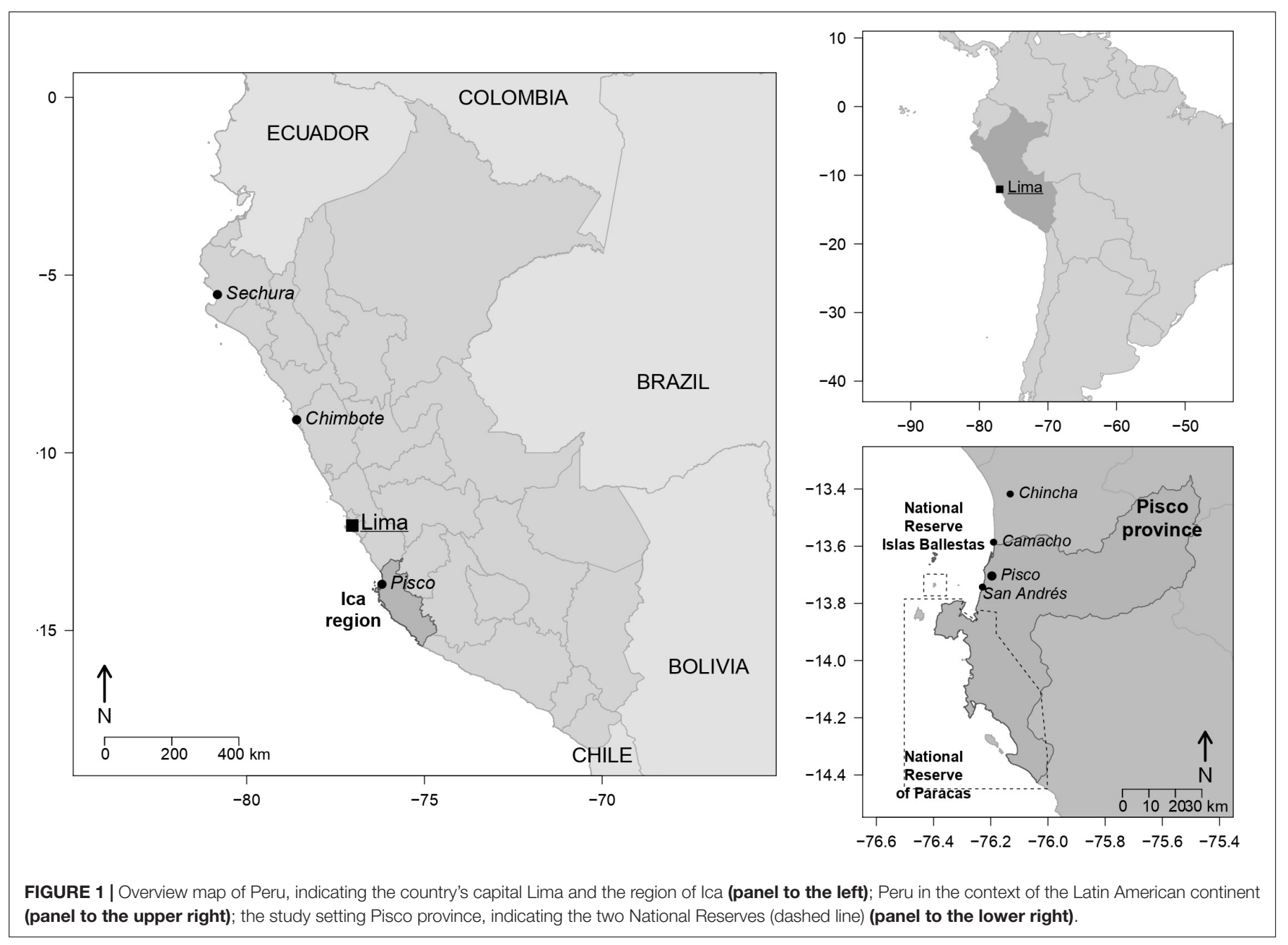

bonito (Sarda chiliensis chiliensis), the Chub mackerel (Scomber japonicus), Cabinza grunt (Isacia conceptionis), Jack mackerel (Trachurus murphyi) and octopods (Octopus mimus) (Castillo et al., 2018, p. 323). Fishing and post-harvest processes provide labor and income to thousands of people in the region. Pisco has the fourth highest number of processing plants for the production of fish meal/oil as well as for the processing of fish and shellfish for direct human consumption (in 2017; Ministerio de la Producción [PRODUCE], 2018, p. 141). Moreover, aquaculture takes place, with 192 ha (in 2017) being officially designated to the culture of the Peruvian bay scallop (Argopecten purpuratus) (Ministerio de la Producción [PRODUCE], 2018, p. 178).

Additionally, the region hosts a flourishing tourist sector, being the third most important region visited by foreign tourists (Comisión de Promoción del Perú para la Exportación y el Turismo [PROMPERÚ], 2017) and receiving up to 3 million national and 0.5 million international visitors per year (in 2018; Ministerio de Comercio Exterior y Turismo [MINCETUR], 2019). The two National Reserves of Islas Ballestas and Paracas, situated at the coast of Pisco province (see Figure 1), are the most frequently visited National Reserves (on the national level; Servicio Nacional de Áreas Naturales Protegidas (Sernanp), 2020). The great biodiversity of birds and sea mammals together with the beaches and sand dunes allow for all kind of recreational activities. The region Ica is also renowned for its agricultural production, with main crops being corn and (sweet) potatoes, grapes, asparagus and tomatoes (Ministerio de Agricultura y riego [MINAGRI], 2018).

Impacts of climate change on eastern boundary upwelling systems (including the HCUS) were argued to likely be profound, though difficult to forecast, because environmental variability is progressively expanding its earlier ranges (Bakun et al., 2015). There is still considerable debate as to whether or not climate change will drive an intensification (Bakun and Weeks, 2008; Narayan et al., 2010; Bakun et al., 2015; Xiu et al., 2018) or decline (Barton et al., 2013) of upwelling in these systems, including the HCUS. Moreover, the HCUS is exposed to the interannual environmental variability induced by the El Niño Southern Oscillation (ENSO) dynamics, affecting both the marine and terrestrial environment and damaging human settlements and their livelihoods along the entire coast. Also, whether or not climate change will induce an intensification and/or increase in frequency of occurrence of El Niño events is still under debate (e.g., Bakun and Weeks, 2008; Collins et al., 2010; Vecchi and Wittenberg, 2010; L'Heureux, 2018), though for some regions, the effects of ENSO events were suggested to be reinforced by climate change effects (Fasullo et al., 2018). 
During its warm phase (El Niño), a cessation in upwelling drastically increases ocean temperatures and reduces primary productivity, while extreme rainfalls and flooding occur in an otherwise arid coast. Effects on the marine living resources and depending fisheries are multifold. While some species struggle to find enough food in times of reduced primary productivity (e.g., anchovies; Niquen et al., 1999; Bertrand et al., 2004), others thrive under increasing water temperatures, resulting in an immigration of offshore and tropical species to nearshore regions (e.g., Chub mackerel Scomber japonicus and Jack mackerel Trachurus murphyi; Niquen et al., 1999). The province of Pisco was also selected as a study setting for this work because effects on the near-shore habitats were, in the past, reportedly very different than that of the upwelling system. In the region, many benthic species suffered from almost tropical conditions (e.g., macroalgae, crabs), while others flourished (e.g., scallops, sea stars, and sea urchins) (Taylor et al., 2008). The Peruvian bay scallop (Argopecten purpuratus), increasing fiftyfold in biomass during the El Niño 1983/84 stipulating a "gold-rush" environment for fishers from all over the country hurrying to make use of this opportunity, is a particular example for effects on fisheries (e.g., Wolff, 1984; Meltzoff et al., 2005; Wolff et al., 2007; Badjeck, 2008; Gonzalez, 2009).

So far, most research has aimed to understand consequences of environmental variability on Peruvian fisheries through a natural science lens, with little attention to the human dimension (but see Meltzoff et al., 2005; Badjeck, 2008; Gonzalez, 2009; Kluger et al., 2018). Given the socio-economic importance of the HCUS and its resources, and the uncertainty associated with foreseeing future disruptive events and climate change effects, the setting provides a rich case for studying possible futures and consequences thereof through a participatory scenario approach.

\section{MATERIALS AND METHODS}

Several literature reviews have emphasized the lack of a single, unifying approach to scenario development while pointing to a number of shared characteristics of existing approaches: the identification of key drivers in a systematic way and their ranking in terms of importance and uncertainty (Amer et al., 2013; Oteros-Rozas et al., 2015). Our work adapts the framework developed by Chermack (2011) to the needs of our study setting (see Figure 2). The first step drew from a two phase online survey as to integrate knowledge from different perspectives in the identification and ranking of drivers of change (see section "Identifying Drivers of Change: Reaching Out Through Online Surveys"); the second step used a participatory stakeholder workshop for developing the scenarios and respective narratives based on a four-cell matrix (see Figure 3) (see section "Developing the Scenarios: A Participatory Stakeholder Workshop"); in a third step, these narratives were enriched and, indeed, confronted with insights, perceptions and interpretations of resource users from the two regional study settings in a series of focus group discussions (see section "Contextualizing the Scenarios: Enriching Scenario Narratives With Vision of Local Stakeholders in Focus Group Discussions"). The combination of these different participative methods allowed us to use a gradual approach to explore the future of the HCUS in collaboration with different stakeholders.

\section{Identifying Drivers of Change: Reaching Out Through Online Surveys}

A two-phase online survey was used to identify potential environmental and socio-economic drivers of change (i.e., "any natural or human-induced factor that directly or indirectly causes a change in an ecosystem," Millennium Ecosystem Assessment [MA], 2005, p. 87) of the HCUS in the future (i.e., 20 years) and their perceived uncertainty and impact. An online survey was used to reach a large number of people (Voinov et al., 2018). It was constructed in English and Spanish using the statistical survey tool LimeSurvey ${ }^{3}$ (LimeSurvey Project Team/Carsten Schmitz, 2012), and consisted of two phases that were open to responses for a 3 weeks' period each during SeptemberNovember 2019.

Potential participants were selected based on whether they were working in the Peruvian marine-coastal environmental sector, be it through research (local and international scientists working on marine-related issues), industry, governmental (representatives of ministries relating to the marine-coastal space) or non-governmental institutions (local and international NGOs). The selection relied on a sampling strategy with multiple entries, i.e., previous professional contacts of the authors, project colleagues, and contacts provided by survey respondents.

For the first survey phase, potential participants $(n=143)$ were invited through an email to which an informative summary document of the research process was attached. Out of 143 contacted persons, 49 responded (response rate: 34\%). The first phase's survey entailed two modules. First, respondent's sociodemographic information was explored, including gender, age, level of completed formal education, current employment sector and country of work and experience working on marinecoastal environments. The majority of survey participants were male, researchers, and specialized in marine ecology and marine governance topics (see Supplementary Material 1). Second, respondents were asked to list as many environmental and socioeconomic factors as they thought would influence the marinecoastal environment in 20 years. For each factor, participants were requested to provide a short explanation on the effect (for details on the survey see Supplementary Material 2). After terminating the first online round, results were analyzed by the first two authors as to standardize and code the answers, and to then cluster them into two categories: general and specific. To ensure rigor, participants' answers were coded separately by the two first authors, to then discuss all drivers' coding through several consensus-building exercises. Whenever disagreement persisted, the other authors engaged in the coding process until an agreement was reached. Overall, the inventory of drivers of change identified contained a total number of 53 drivers of change, 22 environmental and 31 socio-economic (see Table 1) organized in 10 and 12 general categories respectively (see Supplementary Material 3). For the second survey phase, all

${ }^{3}$ www.limesurvey.org 


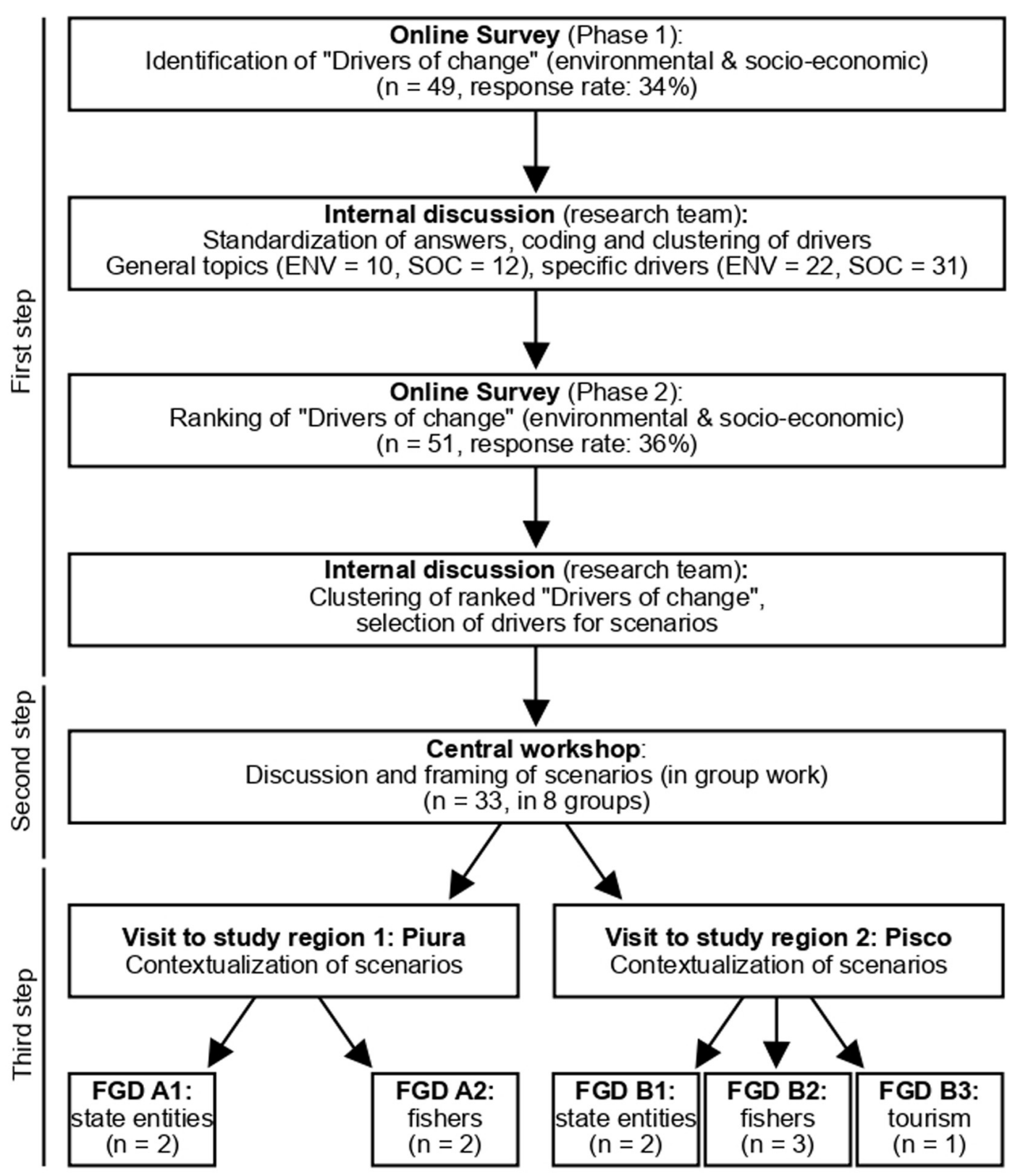

FIGURE 2 | Scheme of the designed participatory method, being divided in three steps. For each step, the sample size and a brief description of the main aim is provided. From top to the bottom: (1) the first step consisted of a two-phase online survey and in between coding of answers (sections "Identifying Drivers of Change: Reaching Out Through Online Surveys" and "Online Survey" of this manuscript); (2) the second step comprised of a central workshop (sections "Developing the Scenarios: A Participatory Stakeholder Workshop" and "Central Workshop"); and (3) the third step included several Focus Group Discussions (FGD) in two coastal regions of Peru (Piura in the north and Pisco in the south; section "Contextualizing the Scenarios: Enriching Scenarios Narratives With Visions of Local Stakeholders in Focus Group Discussions" and "Focus Group Discussions").

(potential) participants despite their (non)-participation in the previous phase were contacted again, only excluding those who had disagreed on being written to again (all but two persons; $n=141)$. In this phase, about a third of the contacted people participated (51 of the 141 contacted; response rate: $36 \%$ ). The results of the first phase (i.e., the list of specific drivers constructed by the first two authors; see Table 1) were used to ask respondents to evaluate the perceived certainty of occurrence of each driver and the magnitude of its impact on the future MSES, based on a five-level scale (see Supplementary Material 4). To avoid positional effects, the order of drivers was randomized for each participant. After terminating this second online survey, mean values of all drivers were plotted along the two scales (certainty of occurrence, impact level) as to visually inspect distribution patterns. The list of driver categories and Figure 4 were visualized in the $\mathrm{R}$ environment ( $\mathrm{R}$ Core Team, 2019) using the ggplot2 


\section{High and Erratic Ocean Variability}

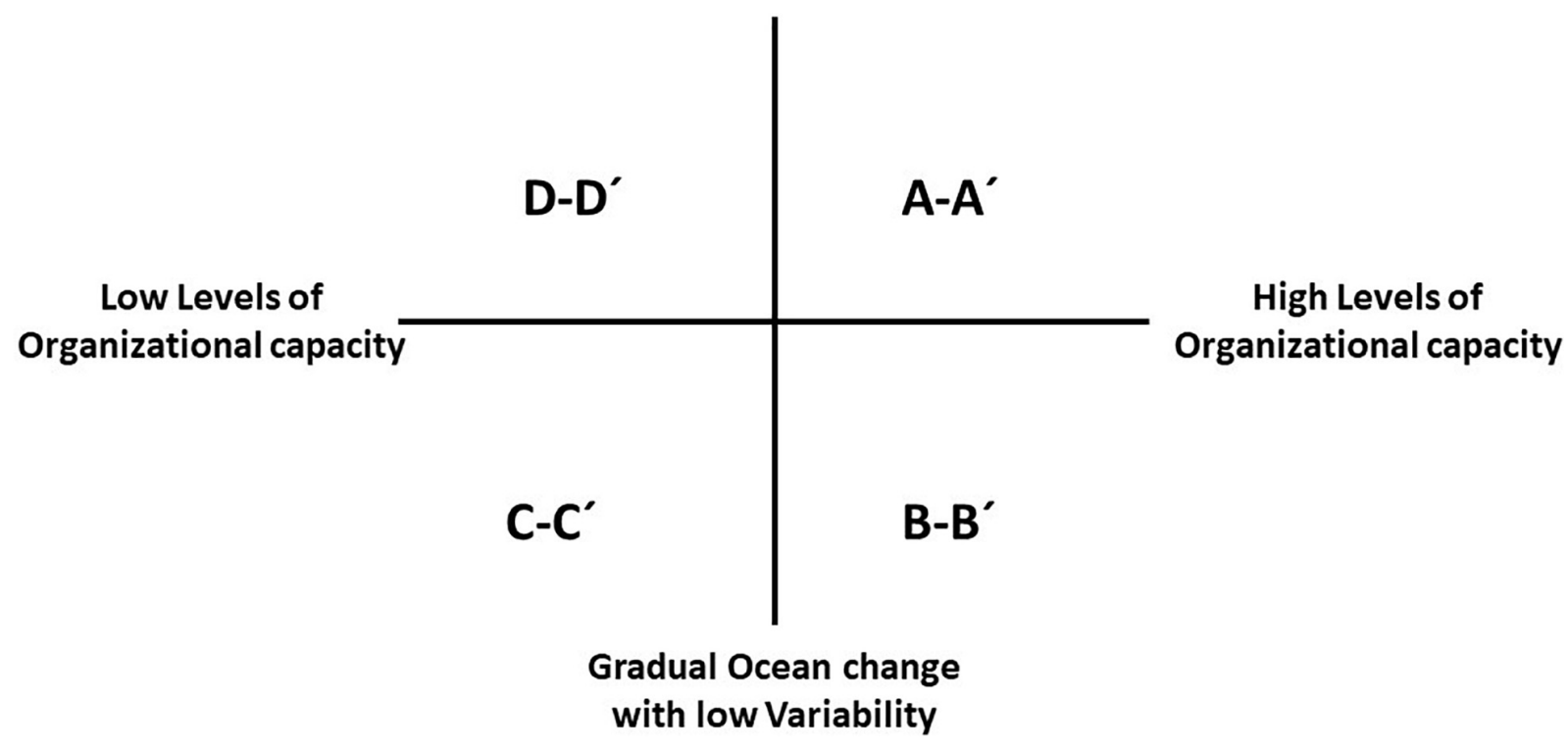

FIGURE $\mathbf{3}$ | Drivers of the axis limiting the quadrants in which each pair of groups $\left(\mathbf{A}-\mathbf{A}^{\prime}, \mathbf{B}-\mathbf{B}^{\prime}, \mathbf{C}-\mathbf{C}^{\prime}, \mathbf{D}-\mathbf{D}^{\prime}\right)$ of the central workshop elaborated the narratives (cf. section "Developing the Scenarios: A Participatory Stakeholder Workshop").

(Wickham, 2016), dplyr (Wickham et al., 2019), viridis (Garnier, 2018), RColorBrewer (Neuwirth, 2014), and cowplot (Wilke, 2019) packages.

\section{Developing the Scenarios: A Participatory Stakeholder Workshop}

The cumulative survey results were then used to construct different narratives of potential futures in the course of a participatory stakeholder workshop that took place in November 2019 in Lima, Peru (central workshop hereinafter). Central workshop participants $(n=33$; of which 19 had been invited to participate in the survey but only 12 had answered) from diverse backgrounds (scientists, representatives of NGO, governmental bodies, and the fisheries sectors) were asked to imagine four alternative futures (see Figure 3).

Before this central workshop, the first two authors used the scatter plot (see Figure 4A) to select those three drivers ranking highest on both scales (i.e., high certainty, high impact: pollution [SOC24], (coastal) human population growth [SOC02], and expansion and diversification of coastal use [SOC06]) to define the boundary conditions for the discussion of possible futures. Second, drivers with the (relatively) highest potential impact and the lowest certainty were identified, with the aim to select from those one environmental and one social driver that should form the axis of the four-cell matrix to be discussed by central workshop participants ( $c f$. Figure 3). Among a group of very closely ranked drivers, we selected two drivers (ocean currents [ENV04] and social cohesion [SOC29]) based on the frequency with which they were mentioned in the first step of the online survey (see Supplementary Material 3). Due to practical reasons, like the better understanding of the drivers to participants, the drivers were later presented under slightly modified names: ocean variability and organizational capacity (the way we refer to them from now on).

In the central workshop, the methodology and results from the online surveys were first presented by the research team. Then, each contextual frame of the four-cell matrix (see Figure 3) was discussed by two of eight heterogeneous (i.e., including people with different expertise) groups (with $n=3-5$ ). Each group was asked to discuss for half an hour how the given guidelines (based on the drivers of change mentioned; $c f$. Supplementary Material 5) would affect the future of the HCUS within a timeline of 20 years. Being asked to note the most important points onto a flipchart, participants also had to agree on a title for their scenario. Then, groups were prompted to discuss questions concerning emerging challenges and sustainability implications for their scenario: What are the challenges for the public policy/civil society/research and technological development that your scenario implies? How could the public policy/civil society/research and technological development promote sustainability in your scenario? After 45 min the exercise was completed, and a representative of each group was invited to share the scenario developed in his*her group with the whole audience.

These presentations were recorded (with the verbal consent of participants) to be afterward analyzed - together with the flipchart content - by the first two authors as to derive consistent narratives for the four scenarios (as presented in section "Central Workshop"). 
TABLE 1 | List of drivers resulting from the coding exercise analysis of the first step (cf. section "Identifying Drivers of Change: Reaching Out Through Online Surveys".

\begin{tabular}{|c|c|c|}
\hline Code & Name & Definition \\
\hline ENV01 & $\begin{array}{l}\text { Algae blooms and small-scale } \\
\text { biogeochemical changes }\end{array}$ & Appearance of red tides or algae blooms, sulphidic and nitrification events \\
\hline ENV02 & $\begin{array}{l}\text { Atmospheric processes and } \\
\text { precipitation regimes }\end{array}$ & $\begin{array}{l}\text { Changes in atmospheric processes such as the South Pacific Anticyclone, Walker circulation; changes in } \\
\text { rainfall pattern modifying ocean salinities }\end{array}$ \\
\hline ENV03 & Coastal geomorphology & Coastal erosion and desiccation processes, changes in river discharge and occurrence of earthquakes \\
\hline ENV04 & Ocean currents & Overall changes in ocean currents and the thermal gradient of the same \\
\hline ENV05 & Ecosystem functioning & Perturbation of the normal conditions of the ecosystems including regime shifts \\
\hline ENV06 & $\begin{array}{l}\text { Expansion Oxygen Minimum Zone } \\
(\mathrm{OMZ})\end{array}$ & Change in the depth of the ocean layer at which oxygen concentration is at its lowest saturation point \\
\hline ENV07 & $\begin{array}{l}\text { Frequency and strength of extreme } \\
\text { events }\end{array}$ & Change in how often and how strong extreme (natural) events occur, not including ENSO events \\
\hline ENV08 & Frequency of ENSO events & Change in how often El Niño Southern Oscillation events occur \\
\hline ENV09 & Strength and variability of ENSO events & Change in how strong and how variable (e.g., different types) of El Niño Southern Oscillation events occur \\
\hline ENV10 & Global warming & Increase in atmospheric temperature \\
\hline ENV11 & Ocean warming & Increase in ocean temperature \\
\hline ENV12 & Oceanographic processes & Changes in tidal regimes, energy distribution \\
\hline ENV13 & Oxygen availability & Changes in availability of dissolved oxygen in the ocean, processes of deoxygenation and anoxia \\
\hline ENV14 & Primary productivity & Changes in the production of biomass by photosynthetic active phytoplankton and other algae in the ocean \\
\hline ENV15 & Sea level rise & Increase in the average sea level, increasingly flooding formerly terrestrial areas \\
\hline ENV16 & Species composition & Appearance of new species and changes in species abundance and trophic chains \\
\hline ENV17 & Species distribution & Changes in where marine species occur, which zones they inhabit \\
\hline ENV18 & Species life cycle traits & Changes in the timing of reproduction (e.g., spawning), growth and life length of marine species \\
\hline ENV19 & Strength of upwelling & Changes in the upwelling intensity, location and/or duration \\
\hline ENV20 & Wind strength & Changes in wind patterns and characteristics (orientation. Intensity, frequency). \\
\hline ENV21 & Natural evolution & Species adaptation and natural selection processes \\
\hline ENV22 & Ocean acidification & Process of decrease in $\mathrm{pH}$ of the ocean due to the uptake of carbon dioxide (CO2). \\
\hline SOC01 & Availability of fossil fuels & Worldwide availability and accessibility of fuel \\
\hline SOC02 & (Coastal) Human population growth & Increase in human population with a focus on coastal areas, including due to migration \\
\hline SOC03 & Corruption & Institutional corruption at different scales \\
\hline SOC04 & Demand of fish meal/fish oil & Changing demand of fish meal/fish oil due to global markets dynamics and aquaculture trends \\
\hline SOC05 & Demand of seafood & $\begin{array}{l}\text { Changing demand of seafood due to changes in consumption, economic incentives or global markets } \\
\text { dynamics }\end{array}$ \\
\hline SOC06 & $\begin{array}{l}\text { Diversification and expansion of coastal } \\
\text { use }\end{array}$ & Growing (multiple) use of coastal space (tourism, extractive industries, urbanization. . .) \\
\hline SOCO7 & Economic equality & Wealth distribution; absolute and relative poverty \\
\hline SOC08 & $\begin{array}{l}\text { Environmental knowledge and } \\
\text { education and training }\end{array}$ & Knowledge and awareness of sustainability; access to education and training programs \\
\hline SOC09 & Fishing effort & Fishing fleet size and exploitation rate of resources \\
\hline SOC10 & Human Health and Food Security & Consumption of contaminated (sea-)food; nutrition of population with seafood \\
\hline SOC11 & Human Migration & Human movement (national and international), not necessarily directed towards coastal areas (see SOC02) \\
\hline SOC12 & Illegal fishing & Fishing with prohibited fishing gear or not respecting minimum sizes \\
\hline SOC13 & Inclusive management & $\begin{array}{l}\text { Management that aims to include women and national/international fisher migrants and to empower fishers' } \\
\text { communities }\end{array}$ \\
\hline SOC14 & Industrial overfishing & Overfishing of anchoveta \\
\hline SOC15 & Informal and undocumented practices & $\begin{array}{l}\text { Informal activities including informal fishing and undocumented bycatch, and missing implementation of } \\
\text { best practices (catch manipulation, processing); under-regulated tourism }\end{array}$ \\
\hline SOC16 & Innovation and technology & Innovative research and implementation of new technological tools \\
\hline SOC17 & Labor and income in fisheries sector & Access to fisheries, fishers' earnings, dependencies of fishers to intermediaries \\
\hline SOC18 & Macro-economic shifts & Inflation, changes in sources of national growth, globalization \\
\hline SOC19 & Monitoring and enforcement of rules & $\begin{array}{l}\text { Control of the marine-coastal activities, traceability and certification schemes; power of institutions to } \\
\text { implement rules }\end{array}$ \\
\hline SOC20 & National aquaculture development & (Spatial) Expansion of Peruvian aquaculture activities, development of new aquaculture types \\
\hline SOC21 & Offer and prices of fish meal/fish oil & Changes in offer and prices of anchoveta \\
\hline SOC22 & Offer and prices of seafood & Changes in offer and prices of seafood \\
\hline
\end{tabular}


TABLE 1 | Continued

\begin{tabular}{|c|c|c|}
\hline Code & Name & Definition \\
\hline SOC23 & Artisanal overfishing & Overexploitation of resources by artisanal fishing fleet \\
\hline SOC24 & General Pollution & Environmental, beach and sea bottom pollution including plastic and microplastics \\
\hline SOC25 & Industrial pollution & Pollution from extractive industries such as heavy metals or oil spills \\
\hline SOC26 & Public investment & National investment in fisheries sector, education, health, infrastructure \\
\hline SOC27 & Regulatory and legal framework & Existing rules and laws to regulate marine activities including fisheries, and resulting problems \\
\hline SOC28 & Organic pollution & Pollution and eutrophication from terrestrial sewages \\
\hline SOC29 & Social cohesión & Social organization, unity and conflict resolution capacity \\
\hline SOC30 & Spatial management & Establishment of protected areas and management schemes that incorporate different marine activities \\
\hline SOC31 & State reform & Transformation of state structure and policies, processes of decentralization and/or privatization \\
\hline
\end{tabular}

For each driver, the respective code (first column), name (second column) and a definition (third column) is provided. The names and definitions showed were the ones presented to participants in the second phase of the first step; for Spanish speaking participants the information was translated.

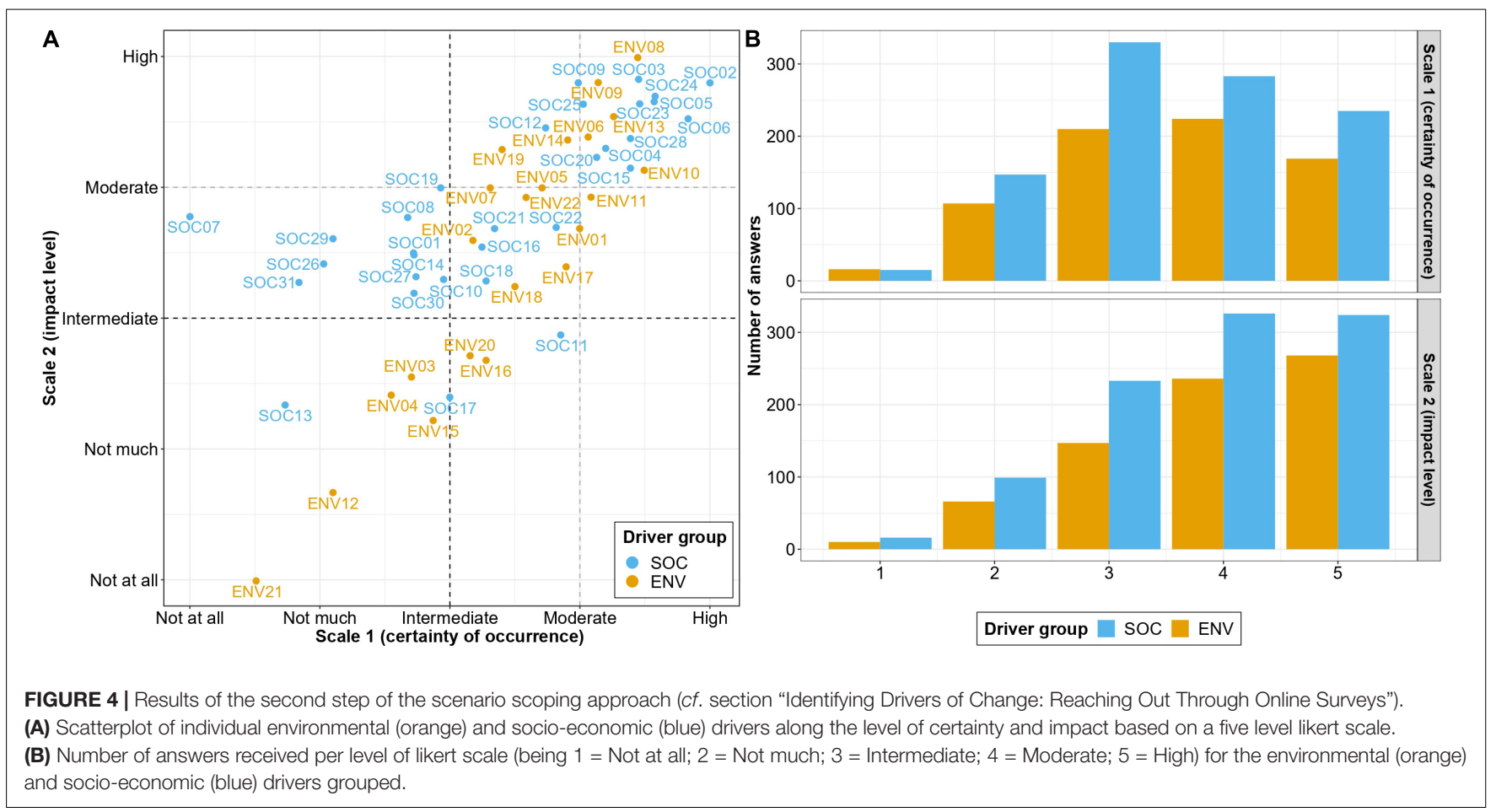

\section{Contextualizing the Scenarios: Enriching Scenario Narratives With Vision of Local Stakeholders in Focus Group Discussions}

In their majority, actors in the central workshop represented central and national institutions (such as representatives from governmental agencies), hence privileging a centralized vision on the Peruvian marine-coastal environment. Thus, in the third step of our research process we took the results of the scenario exercise to actors in two study regions with the aim to contrast and complement the narratives formulated in the central workshop with the vision of regional actors (fishers, mussel farmers, tourism operators, regional state representatives, practitioners). We conducted a total of ten focus group discussions (FGD) in the regions of Ica and Piura ( $c f$. Figure 1) between late November and early December 2019 (cf. Figure 2). Events with fishers and regional entities were held separately in both study areas as to encourage freedom of speech.

To open the discussion on how the Peruvian MSES might look like in the future, FGD participants were asked to imagine different specific situations that linked back to the key environmental and socio-economic drivers used for the fourcell matrix discussed in the central workshop. To concretize these drivers, we used examples for both gradual and erratic environmental (ocean) change such as the disappearance of a certain key species or changes in wind patterns for the environmental sphere and massive migration toward the coast or shifts in seafood market prices for the socio-economic dimension. Additionally, the response to those circumstances was explored at different levels of social organization through questions on how participants expected the state, their social organization and 
themselves to deal with the new situations. Emerging common themes were explored and comparatively discussed in the context of the previously constructed scenario narratives.

For the purpose of providing exemplary insights into diverging and converging interpretations and positions with regard to the topics covered in both central and study regions workshop initiatives, we draw in the following on the focus groups held with the marine resource users (fishers) in the province of Pisco (Ica region). Participants were mostly male artisanal fishers ( $n=12$; only one woman was present) and a diversity of fishing gears and fishing practices was represented such as artisanal fishers of anchoveta (Engraulis ringens) from San Andrés, fishers targeting multiple species from Chincha and non-embarked fishers (i.e., fishers that fish from the shore or very close from it without a vessel) from Camacho. Two of the three FGD were heterogenous in spatial terms (i.e., including fishers from different parts of the region) while the remaining third group was homogeneous. Discussions in FGD were about 6090 min long and guided by the authors, purposefully engaging in the emerging discussions and remaining flexible with regard to their structure. Data was coded by the first author aiming at the identification of general topics that allowed the structuring of the material and the identification of convergences and differences among participants' answers.

A detailed, in-depth analysis of stakeholders contrasting visions using material from all FGDs is part of an ongoing, complementary discussions among the authors and will be published in a separate manuscript.

\section{RESULTS}

\section{Online Survey Phase I}

The number of answers per category was 107 for the environmental system and 207 for the socio-economic one. The median of drivers mentioned by participants was 4 for the environmental and 3 for the socio-economic. Resulting in the identification of a total number of 53 drivers of change: 22 environmental and 31 socio-economic (see Table 1) organized in 10 and 12 general categories respectively (see Supplementary Material 3).

Interestingly, climate change appeared as a common global phenomenon umbrella, cross cutting all but two environmental drivers (see Supplementary Material 3; [ENV21] and [ENV19]). However, regarding socio-economic drivers of change only a few answers appeared connected to global phenomena; for instance, the demand and offer of seafood/fish meal/oil were linked to market forces or drivers such as SOC19 and SOC27 that were connected to governability.

\section{Phase II}

A slightly smaller number of participants answered the ranking questions for socio-economic drivers (63\%) than for the environmental ones (68\%) despite the higher return of socioeconomic answers in the previous phase. The percentage of participants replying to the questions about impact level and certainty of occurrence did not differ. Moreover, a higher number of socio-economic drivers were ranked as having a big impact when compared to environmental ones; the same holds true for the level of certainty (see Figure 4B).

Environmental drivers appeared more lineally distributed on the impact/certainty sphere (see Figure $4 \mathrm{~A}$ in orange) than socioeconomic drivers (see Figure $\mathbf{4 A}$ in blue). For the latest, two clusters are distinguished. One group, together with the majority of environmental drivers (except for ENV21, ENV12), fell into the top right quadrant, were impact and certainty are high; the other distinguished group of socio-economic drivers clustered in the center, were impact and certainty are intermediate (see Figure $4 \mathrm{~A}$ in blue).

\section{Central Workshop}

The vertical axis of the four-cell matrix used as an input for the central workshop (i.e., Figure 3) represented the environmental variability of the ocean that could in the future evolve in two directions: (1) a "gradual ocean change with low variability" defined as an environment where the sea temperature gradually increased, changing marine species composition and abundance but the gradual increase allows predictability with models; and (2) a "high and erratic ocean variability" referring to unstable environmental patterns leading to unpredictable changes (i.e., strong fluctuations in environmental conditions). The horizontal axis represented two extremes in organizational capacity: one where formal and informal institutions are well developed and one in which the organizational capacity is low. The implication on what the organizational capacity meant, for example when it came to the enforcement or effectiveness of norms in place was left open for interpretation. On top of this, as described in detail in section "Developing the Scenarios: A Participatory Stakeholder Workshop," three other drivers of change (i.e., pollution, (coastal) human population growth and expansion and diversification of coastal use) made up the boundary conditions. As a result, in all futures pollution, especially plastic, industrial and urban pollution, are affecting fishing and coastal activities (tourism, oil exploitation and urban development) in addition to human health.

In the central workshop, the following four scenarios were constructed by the participants. The narratives and titles of the scenarios are an accurate synthesis and translation from the existing options that participants provided, however, they have not yet been checked with participants.

\section{Scenario A: "Together, Adaptation Is Possible"}

In 20 years' time, the use of the ecosystem services and resources of the HCUS has intensified. Ocean characteristics such as water temperature and species composition and distribution are highly fluctuating spatially and temporally. This has increased the uncertainty for research and technology to develop models and address the existing problems. As a result, extreme events are stronger and more frequent, increasing the vulnerability of coastal human communities due to strong rains and subsequent flooding; furthermore, fisheries have to deal with changing natural habitats and reproductive spaces of key valuable species. The demand for primary products exports from Peru is 
significantly higher and informal settlements in coastal areas have grown. At the same time, conflicts between fishers and industries such as tourism and oil exploitation are taking place due to the weak intersectoral coordination of public policy regarding spatial planning. However, the organizational capacity is strong, reflected in a stronger collaboration between society and science, a high user's awareness of the importance of sustainable use of resources, and the need to develop successful resource management plans. Regarding the latter, social organizations believe that management plans should not only consider living marine resources but also waste management and the creation of new marine protected areas.

\section{Scenario B: "We Need to Know"}

In 20 years' time, a gradual increase of sea temperature and a decrease in the variability of ocean characteristics are causing a progressive change in the abundance and distribution of certain living marine resources. Therefore, some resources are no longer available in some areas; this new resource availability has led to changes in human consumption habits. Fortunately, fishers show an enhanced response capacity, for example by migrating to more favorable fishing areas, because the low environmental variability allows for longer-termed planning. This greater adaptive capacity has also been favored by the increase in organizational capacity helping to take better advantages of the available resources. Likewise, the strong organizational capacity increases the demand of information, education and technology. However, the research and technological institutions are struggling with their scientific communication strategies in a moment where the opportunity to increase user's awareness about sustainability through knowledge is more real than ever. Moreover, social organizations are demanding a new regulatory framework to tackle the existing conflicts between fishers and tourist operators over the use of space. This demand has put social equity, power and representation struggles on the table and public policy is urged to implement bottom-up governance initiatives and design flexible adaptive management plans. Furthermore, research and technological institutions are taking advantage of the organizational capacity by increasingly working together with local communities' traditional local knowledge and broadening their research scope as to embrace interdisciplinarity.

\section{Scenario C: "Not Looking Good"}

In 20 years' time, eutrophication processes are more frequent. Ecosystems such as mangroves and wetlands and refuge areas for species are smaller and biogeochemical parameters such as the increase in the oxygen minimum zone and the stratification of ocean waters are observable. Also, sea temperature changes have altered the average size of key species and trophic regimes, leading to the extinction of some species and the overexploitation of others. An ever-growing environmental pollution puts at risk both human health and the trust of marketing channels for the Peruvian seafood through the increased threat for spread of diseases. This negatively affects the national economy and the income of communities. Additionally, fishers need to travel longer distances to find fish of good quality. This lower income per capita is exacerbated by a decrease in the organizational capacity which allows intermediaries and companies to obtain higher percentages of the benefits, and social inequality is high. The presence of illegal and undocumented fishing has increased in response to the decrease in income, fishers are searching other seafood products with which to generate profit. Furthermore, the state is lacking capacity to monitor and control the fisheries activity. Society and in particular users of the marine space struggle with diversifying their activities and alternative livelihoods to fishing, e.g., in the agriculture sector, are rare, because droughts are more frequent and the agricultural sector is in crisis. The low social cohesion restricts society to effectively participate and commit to problem solving strategies. Under this scenario, public policy is aiming to reduce the competencies of local governments and is in search of new management tools that help mitigate the effects of the environmental impacts. Research and technological institutions work toward strengthening the interdisciplinary scope of their work to generate new knowledge useful for society.

\section{Scenario D: "Chaos Is Back"}

In 20 years' time, the HCUS partially mirrors the situation of Peru during the 1980s, when a mass migration from the interior of the country to Lima had occurred. The MSES is characterized by an erratic environmental variability with more frequent ENSO events and scarcity of marine living resources. The high environmental variability has strong economic implications for society, and renders the development of mid-/long-term management plans difficult. The lack of organizational capacity and the low predictability of environmental changes complicates the creation of scientific knowledge that is needed to manage the resources with a minimum degree of certainty. This uncertainty also translates into an increase of informal activities: users are adopting individual coping strategies, each one doing what they possibly can, because all communal self-management is lost, delinquency is on the rise and social conflicts are serious. The governability is very difficult as functional institutions cease to exist and the state is increasingly opting for top-down strategies to get the situation under control.

\section{Focus Group Discussions}

Participants were asked to imagine three situations of change. First, the disappearance of key species [e.g., anchoveta, mojarra (Gerreidae)]; second, a migration movement of people toward coastal regions and the fishing sector; and third, the increase in the price of a (currently) non-economically valuable species such as the minor stardrum Stellifer minor (Sciaenidae) or fishes from the genus Torpedo. When participants were exposed to the mentioned potential future settings, three themes appeared frequently and were discussed as very relevant. In addition, differences and agreements between fishers appeared.

The first important theme was the role of the state in the management of the fisheries sector in the past, present and future, and how fishers perceived this role. For instance, the current lack of control that the state has on who goes fishing or the future dependence on the state in order to extract the resources as it is written in the constitution were discussed in the context of the second and third settings respectively. Moreover, it was 
maintained that management schemes have changed in the past to the advantage of the industrial fleet, leading to increasingly unequal social conditions.

\begin{abstract}
"In the 70s, there was a law that favored all of us [fishers] but unfortunately when they [the state] saw the potential benefit, they came with a new general fishing law. So, what happens? They take us away, they give them [the industrial fleet] what we [the artisanal fishers] fished before, mackerel [Trachurus murphyi and Scomber japonicus peruanus], bonito [Sarda chiliensis] (...) the artisanal fishers are over because there was no longer a mackerel fishing season. .." (FGD3; 22 November 2019).
\end{abstract}

Furthermore, all fishers complained about both the lack of (institutional) support the artisanal fleet received in comparison to the industrial one, and about bureaucratic hurdles when trying to access funding or to present development projects; claiming that in the future the state needs - above all - to grow an interest in the artisanal sector. Also, all fishers stressed that the state should be more efficient regulating activities that are currently threatening fishing, such as tourism and urban development. Moreover, fishers from San Andrés stated that through a higher organizational capacity (i.e., sharing common goals, being coordinated, self-managing) they would be able to build up sufficient pressure to make artisanal fishers' voices heard and galvanize changes in current management schemes. Fishers from San Andrés highlighted how the reforms of the Peruvian labor laws has weakened fishers' organizational capacity by increasing their division, resulting in a loss of the capacity to claim new regulations, unity and common visions for the future.

\footnotetext{
"If we are united, and fishers react to our call, we strike at a national level and demand the government to implement management schemes that safeguard fisheries resources, such as the anchoveta" (FGD3; 22 November 2019).

"The state arrived (let's say in the 2000s) so in the 90s fishers were recognized at a national level, we pushed back the state and removed rules (...) and then the doors were opened so that four, five fishers could make associations. Right now, there are 200-300 (...) and if we do not manage to consolidate as before, we will continue like this all our lives, lamenting, and our children will continue to lament, until they find a solution, because nobody is going to give it to them, rights are defended with fighting" (FGD3; 22 November 2019).
}

In agreement, fishers from Chincha believed that an increase in the organizational capacity could reduce the negative effects from development projects, while increasing benefits. In contrast, fishers from Camacho saw as almost impossible the possibility to stop or modify development projects; mainly due to the power of big companies and the minimum influence they could exert themselves. In this regard, the need to improve the dialogue between actors while addressing power issues was stressed; fishers perceived that despite often being invited to talk about development project, their concerns and knowledge were very often not considered.

Issues of social equity also appeared when fishers discussed the first and second settings and was again linked to the management regarding the current informal situation of Venezuelan fishing crew members. Fishers stressed that in a future of key species disappearance the associations should support and coordinate responses to help the most vulnerable fishers. In the second scenario, fishers from Chincha expressed that they were already feeling displaced by the arrival of migrants to the fisheries sector mainly because again, they tend to accept lower wages. This as mentioned was believed to complicate future adaptations and therefore fishers expressed the need for the state to implement a decent minimum wage. Moreover, fishers from San Andrés described how state impediments to issue new fishing permits leads to an increase in informal fishing by migrants despite the efforts of their social organizations to try to formalize migrants and allow them to become members of the association.

\begin{abstract}
"We currently have a lot of Venezuelans fishing without permits, the government has not foreseen it." "Venezuelans are not operating as members here, of the union. The port authorities are preventing us from making them members of the union because we cannot give them the permit to become fisher [which is mandatory to be part of an association]; we have fought, we have gone to speak with the port captain so that he allows them to work, so that they are not marginalized in their work (...) they have come, we have trained them. .." (FGD3; 22 November 2019).
\end{abstract}

The second important theme was the role of and trust in knowledge and technology. Regarding this, fishers did not extol scientific knowledge or technology other than to comment that certain adaptive strategies are partially limited by the lack of it; such as fishing further from the coast and for other type of species for which technology and/or knowledge would be needed. Moreover, non-embarked fishers from Camacho expressed that their knowledge and relationship with IMARPE (the Peruvian Research Institute of the Sea; namely the most important scientific institution of the country) is non-existent. However, fishers were concerned with the lack of recognition for their traditional ecological knowledge (TEK) and the doubtful use of scientific knowledge made by some companies in order to gain concessions for tourism development for example. More generally, artisanal fishers from San Andrés articulated mistrust toward scientific knowledge and how this was even been misused to pursue the interests of other actors.

\footnotetext{
“... According to the laws you have to do an environmental impact assessment for every project, they [a company] have started to do it, we have participated in one workshop, nothing more. We have told the engineer what we know, that if you construct the seawall the currents will be disturbed and there will be no longer fishing there... But the classical move of every company, they say no that is not true according to the studies that we have done (...)" (FGD2; 22 November 2019).

"They [scientists] work and give a false report regarding fish volumes; that false information is being used to grant the quotas to those [industrials] who fish" - (FGD3; 22 November 2019).
}

A third common theme was the way in which the responses to proposed changes were elaborated, drawing on past experiences rather than speculating or exploring the future in a creative manner. For example, participants from Camacho related to the potential disappearance of the key species by discussing past pollution events (and the adaptation process to them) that appeared after the settlement of industrial companies. 
Additionally, when discussing the possibility of a high number of migrant fishers arriving to the area to take part in fishing, all participants engaged with the past by highlighting several occasions where this influx of people had already happened. Finally, the possibility of an increase in price of a presently noneconomically valuable species stipulated a discussion, in which there was a general consensus on the perception that historically, whenever market dynamics had resulted in a rise of a species' economic value, the artisanal fleet had been deprived of the right to continue extracting this resource - in favor of the industrial fleet and the big investors:

\begin{abstract}
"Do you think that when a species has a big value, the state offers the fishing possibilities to the industrial fleet instead to the artisanal? Of course (...) there is a little bit of diamonds and everything goes away. This current [Humboldt Current] brought the Peruvian Scallop (...) and what did the government do after seeing that fishers were growing? close its extraction" (FGD3; 22 November 2019).
\end{abstract}

\section{DISCUSSION}

The contextualized scenarios presented here are fictional pieces that aim to highlight and explore different ways in which the HCUS could develop over the coming decades. The future could unfold in ways that contain elements of the different narratives and it will also contain elements that have not been anticipated. The results from the first step of our participatory exercise showed the belief of survey participants that, on the one hand, the identified socio-economic drivers will have a higher impact in the future than natural factors, and on the other, they were also slightly more convinced about their occurrence.

Our study provides insights into some important factors that could shape the future of the HCUS and mostly shows the importance of the contextualization of future studies through on one hand the commonalities and divergences found between the four visions about the future created by participants during the workshops and the themes of the FGDs; and on the other, through the differences, that lay on their area of fishing or fishing practice, between fishers during the FGDs that have been mentioned in the previous section.

Firstly, the four scenarios showed the commonality that they all describe the presence of strong social conflicts between fishers, the tourist sector and other industries mainly as a result of growing and diversifying use of coastal areas. This aligns with what was raised by fishers during the FGD although other participants remarked that some fishers have shifted their activity toward tourism.

In our work we also found that the ways of engaging toward imagining alternative futures differed between the central workshop and the FGD; this highlights the need to think about the challenges of the intercultural/interdisciplinary dialogue. Fishers engage with the scenarios recalling past experiences while participants of the central workshop did so in a much more limited way; only the scenario D ("Chaos is back") also referred to past events.
Differences became also visible with regard to how the scenarios addressed social equity in the future. In scenario B ("We need to know") equity has become a social demand while in scenario C ("not looking good") inequality was described to be deepened especially due to unequal benefits along the commercialization value chain, exacerbated by a weak social organization. This view aligns with what fishers commented when they imagined a situation in which an increase in the organizational capacity could lead to a different regulation of prices that would benefit them more ["Right now we have a market with a maximum purchasing power what would happen if we begin to regulate our prices? (...) they would rise"- FGD3; 22 November 2019]. As seen in section "Focus Group Discussions," in general, fishers expressed a strong concern of social and economic equity and solidarity toward the most vulnerable for the future and migrants ("we fisher have learned that there is a way in which we can all win")- (FGD3; 22 November 2019). Additionally, different sources of knowledge received diverging attention in the two sets of workshops: while FGD participants stressed the lack of TEK recognition as a common problem of many management initiatives, participants of the central workshop (dominated by scientists and centralized governance actors) highlighted the need to integrate TEK in only one of four scenario narratives, and rather emphasized the need to produce more scientific knowledge as to be able to cope with the different futures.

It was also a general result that both, positive and negative visions about the future of central workshop participants were strongly shaped by the social axis (i.e., organizational capacity). As a result, the scenarios in which the organizational capacity was high (A "Together adaptation is possible" and B "We need to know") were considered positive scenarios and participants of both groups used words such as successful, very good or optimistic to define the imagined futures, irrespective of the environmental axis. A higher organizational capacity was believed to favor the sustainable use of resources; it was interpreted as a closer collaboration between society and science and as an increase in the demand for scientific knowledge, technology and new regulatory frameworks. In contrast, during the FGD despite the fact that participants did mention examples of collaboration between fishers' associations and state institutions such as the National Service of Natural Protected Areas, they did not engage with the need for an increase in scientific knowledge. However, as seen in section "Focus Group Discussions," a relationship between the organizational capacity and the capacity to influence regulatory frameworks did appear. This again highlights the importance of scale as it reveals the need to consider the power which organizations at certain spatial scales can exercise over others at other, either higher or lower, scales.

Scientific knowledge production was linked to the adaptive capacities (of users, society, the state) in all four scenarios. The four narratives describe futures in which the production of scientific knowledge is compromised by the uncertainty of environmental variability and how this negatively affects problem solving capacity and issues of sustainability. However, as was shown above, the artisanal fishers did not make this connection during the FGDs. This connection shows, in line with 
other studies (Planque et al., 2019), a limit of many scenario processes, i.e., the tendency of participants to assume that being prepared for the future is linked to the capacity to predict the future. In a similar vein, it is usually assumed that a better understanding of the nexus between the elements and drivers of change leads to sustainability but the truth is that integrated analytical approaches that can be translated into coherent crosssectorial scale policies are often lacking (Yung et al., 2019). Furthermore, several studies have shown how different actors can have different understandings of sustainability (FernándezLlamazares and Virtanen, 2020) and therefore the need to consider future transformations toward sustainability in a more plural and political way (Blythe et al., 2018).

For instance, at a national level, sustainability of the MSES is understood in social, economic and environmental terms following an international definition (Food, and Agriculture Organization of the United Nations [FAO], 1999), and its importance is justified under the terms of SDG 14 "Life below water" ( $c f$. national marine policy D.S 012-2019-DE). It is stressed that it is up to the state to promote and propose measures and policies that strengthen the management of the marine-coastal environment and ensure the contribution of ecosystems and their resources to the current and future well-being of the nation (National Marine Policy, 2019). This position stands in contrast with visions from the FGDs where some fishers were very critical toward the states' notion of sustainability, especially regarding resource extraction. Fishers from San Andrés mentioned the need for the state to implement the existing laws, as not all laws are negative, and prevent the disappearance of key species, especially its reproductive and feeding areas. According to fishers, the state is not currently promoting sustainability measures which are needed to allow adaptation to change; and it does not go to the root of the sustainability problem as the existing laws prevent this.

\footnotetext{
“That word: sustainability, is pretty isn't it? For a species to last every year and to leave it to our children as an inheritance; but that is not so, why? Because we have a root problem (...) and we do not attack it, why? Because laws are made for that. .." (FGD3; 22 November 2019).
}

When we asked participants from the central workshop about notions of sustainability in their scenarios we found that these notions circled around two major themes, largely independent of the four contrasting scenario contexts: (1) Individual and community responsibility; (2) Techno-scientific and knowledge driven solutions. The first notion partially contrasts with participants of the FGDs. First, fishers highlighted that they already cared about sustainability ("we [artisanal fishers] have learnt to differentiate between overfishing and conservation" FGD3; 22 November 2019); for instance, by stressing the importance of fishing the correct sizes of fish or by describing own attempts to establish self-management schemes of resource extraction that would contribute to sustainability. Second, they problematized that fishers were considered as a homogenous group even though big differences in fishing practices could be found both between the industrial and the artisanal fleet and within the artisanal fleet. Claiming that the state actors blamed the fishing practices of the artisanal fleet for the bad status of marine resources, without acknowledging the role of the industrial fleet, fishing major shares of catches ("we are identified as artisanal fishers and as so we are all predators. It is not like that, there is a big difference, while one [industrials] uses a boat of 200 to 1000 tons, us [artisanal fisher] use 20 tons ones" FGD3; 22 November 2019). And third, that the sustainability problem is not one of individual action but would require system change. In this context, fishers expressed their perception of constantly being asked for a greater commitment toward sustainability, through for instance the development of marine protected areas; however, they mention that project development ideas that they have and could benefit the MSES and their communities are usually not discussed. Despite all this, fishers also stated their willingness to increasingly engage with sustainable resource management, especially with respect to tackling potentially unsustainable practices emerging from individualism.

\footnotetext{
"Nature has given us everything (...) it gives us all, but we are not doing anything to help nature defend itself a little, and say, well, let me rest then, help me a little; and artisanal fishing has evolved, we have now purse seines; and we also have to admit that sometimes we have failed to maintain the responsible fishing" (FGD3; 22 November 2019).
}

Here again the issue of scale becomes relevant. For instance, when discussing with FGD participants the abrupt increase in economic value of a single species, several fishers expressed their concern that this could result in the overexploitation of the resource, while others emphasized it would be important to try to prolong this phase (fishers agreed that such a development would necessarily be something temporary) by extracting it in a sustainable manner. Moreover, some fishers discussed the potential of such an event to decrease the organizational capacity of organizations, whereas others thought that the associations could have the opportunity to grow as an institution and for instance, build boats to be able to fish in open waters or conduct development projects. Other fishers from San Andrés also believed that sudden changes in resource prices could provide opportunities, e.g., to allow the association to create companies for younger generations. This is a clear example on how not only global drivers impact sustainability on the local and regional social-ecological scales but how sustainability can also be impacted by bottom-up processes (Nayak and Berkes, 2014).

Secondly, the role of techno-scientific solutions was also identified at the national level as a key variable for the future of the national marine system (i.e., "development of science, technology and innovation in the maritime environment," National Marine Policy, 2019). At the institutional level, this is translated into an increase in the number of people with professional and scientific capacities and in the financial resources toward research, technology and innovation; the aim thereof is to improve the profitability, eco-efficiency and the sustainable use of living and non-living resources, and ecosystem services in the marine environment. However, scholars have argued that the focus on technical strategies as solutions is not necessarily helpful to develop transformations of complex SESs (Moore et al., 2014). As shown, fishers only engaged with technological and scientific innovations as a mean toward 
recovering their activity in times of scarcity. Finally, the fact that their notions of sustainability for uncertain scenarios align with global vision points out to what Bendor (2018) believes to be a deep-seated inability as individuals and as a collective to imagine what a sustainable future may look like, rooted in a general crisis of our social, economic and political imaginaries.

\section{CONCLUSION}

To the best of our knowledge, this paper is the first attempt to explore the future(s) of the marine-coastal social-ecological environment of Peru in a participatory way. This study has provided a preliminary catalog of factors perceived to be important by researchers, decision-makers, and users in the future of the HCUS. Our results, emphasize the importance to acknowledge the intricate uncertainties that are part of plausible future trajectories, including potentially contested issues such as diverging notions of sustainability and power dynamics in decision-making that are due to differences in resources and organizational capacity.

The focus group discussion, in particular, i.e., the third step in the multi-step participatory method presented here, has highlighted the need to contextualize scenarios in regional and local settings. With the aim to address local concerns and power asymmetries, this can be done by exploring the scientific uncertainty regarding the future effects of global change in the HCUS and analyzing contrasting and common visions between and within spatial scales and organizational levels. This regional and local contextualization brings nuance to global models and national narratives, highlighting the diverse positions of local actors, concerning political dynamics as well as broader issues of knowledge production. Notably, different interpretations of sustainability were articulated - ranging from a technocratic understanding paired with a neo-liberal economic vision to transformative approaches that embrace localized political, economic, and ecological alternatives. Moreover, the engagement with local and regional actor brought trade-offs to the fore regarding the capacity to adapt and the role accorded to technological development. As we have shown, resource users may have different reference points in their adaptation imaginaries than scientists and public resource managers. For example, the former tended to rely more strongly on experiences from historic adaptation processes while the latter often privilege technoscientific solutions. Our multi-step participatory method allowed stakeholders to generate MSES narratives of the future through a collaborative process, collecting and acknowledging such multiple perspectives. This provides a basis for all approaches aiming to incorporate knowledge on the social dynamics that would allow transitioning to more democratic and legitimate policies toward the future.

The work presented here allows researchers, managers, and users to jointly engage in participatory management to act in a more effective and robust manner in the face of unpredictable future change. At the same time, these scenarios scoping processes can provide input for modeling, e.g., when exploring the future of resource extraction in a quantitative manner. Often focusing on ecological drivers exclusively, traditional quantitative modeling has tended to portray fisheries systems as platonic worlds of model assumptions. Incorporating local socio-political contexts of fisheries settings and exploring stakeholder views can shed light on critical relations - that are invisible at first sight. As we have shown, the adopted foresight process can, for example, reveal interdependencies of drivers and critical social and economic aspects of the system. The contextualized, co-developed scenarios hence provide further value to modeling approaches exploring more relevant futures and co-producing knowledge for those in charge of subsequent decision-making processes. On a methodological level, our experience suggest that such scenarios must be further developed to include systematic feedback from the collaborative partners in an iterative manner, thus enabling their reflexive improvement.

\section{DATA AVAILABILITY STATEMENT}

The datasets generated for this study are available on request to the corresponding author.

\section{ETHICS STATEMENT}

Ethical review and approval was not required for the study on human participants, in accordance with the local legislation and institutional requirements. The participants provided a recorded statement indicating informed consent to participate in this study.

\section{AUTHOR CONTRIBUTIONS}

MG, LK, and MF designed the research and wrote the first draft of the manuscript. MG and LK conducted the online research and analyzed the data. MG constructed the Figure 3 and Supplementary Materials 1, 2, 4, 5. LK constructed the Figures 1, 2, 4 and Supplementary Material 3. IG, GD, MG, and LK conducted the fieldwork research in Peru. All the authors contributed to manuscript revision, read, and approved the submitted version.

\section{FUNDING}

This manuscript was prepared as part of the bilateral project "Social-Ecological Tipping Points of the Northern Humboldt Current Upwelling System, Economic Repercussions and Governance Strategies" (Humboldt Tipping, https://humboldttipping.org/) funded by the German Federal Ministry of Education and Research (BMBF) within the framework of the international and Interdisciplinary programme "EcoBiological 
Tipping Points (BioTip)" (https://www.fona.de/en/measures/ funding-measures/biotip.php) through the grant 01LC1823E.

\section{ACKNOWLEDGMENTS}

Our thanks go to all the people who kindly participated in our research: in our online surveys, personal interviews, workshops and focus group discussions. Special thanks to IMARPE for hosting and helping in the organization of the workshop in Lima.

\section{REFERENCES}

Agrawal, A. (1995). Dismantling the divide between indigenous and scientific knowledge. Dev. Change 26, 413-439. doi: 10.1111/j.1467-7660.1995.tb0 0560.x

Alcamo, J. (2001). Scenarios as tools for international environmental assessment (No. 5). Copenhagen: European Environment Agency.

Alvarez, J. (2003). Estudio sobre el impacto socioeconómico de la pesca artesanal en los Estados Miembros de la Comisión Permanente del Pacífico Sur. Reporte preparado para la Secretaria General-Dirección de Asuntos Económicos de la CPPS 27.

Amer, M., Daim, T. U., and Jetter, A. (2013). A review of scenario planning. Futures 46, 23-40. doi: 10.1016/j.futures.2012.10.003

Badjeck, M. C. (2008). Vulnerability of Coastal Fishing Communities to Climate Variability and Change: Implications for Fisheries Livelihoods and Management in Peru. Thesis, University of Bremen: Bremen.dissertationthesis

Badjeck, M. C., Katikiro, R. E., Flitner, M., Diop, N., and Schwerdtner, K. (2011). Envisioning 2050: climate change, aquaculture and fisheries in west Africa. Dakar. Senegal, 14-16 April 2010. WorldFish Center Workshop Report No. 2011-09 Penang: The World Fish Center Workshop Report No. 201109.

Bakun, A., Black, B. A., Bograd, S. J., García-Reyes, M., Miller, A. J., Rykaczewski, R. R., et al. (2015). Anticipated effects of climate change on coastal upwelling ecosystems. Curr. Clim. Change Rep. 1, 85-93. doi: 10.1007/s40641-0150008-4

Bakun, A., and Weeks, S. J. (2008). The marine ecosystem off Peru: what are the secrets of its fishery productivity and what might its future hold? Prog. Oceanography 79, 290-299. doi: 10.1016/j.pocean.2008.10.027

Barton, E. D., Field, D. B., and Roy, C. (2013). Canary current upwelling: more or less? Prog. Oceanography 116, 167-178. doi: 10.1016/j.pocean.2013.07.007

Bendor, R. (2018). Imagination. in Interactive Media for Sustainability 129-164. Cham: Palgrave Macmillan. doi: 10.1007/978-3-319-70383-1_5

Béné, C. (2006). Small-scale Fisheries: Assessing Their Contribution to Rural Livelihoods in Developing Countries. FAO Fisheries Circular No. 1008 FIPL/C1008 (En) Rome: FAO.

Béné, C., Barange, M., Subasinghe, R., Pinstrup-Andersen, P., Merino, G., Hemre, G. I., et al. (2015). Feeding 9 billion by 2050-Putting fish back on the menu. Food Secur. 7, 261-274. doi: 10.1007/s12571-015-04

Bertrand, A., Segura, M., Gutiérrez, M., and Vásquez, L. (2004). From smallscale habitat loopholes to decadal cycles: a habitat-based hypothesis explaining fluctuation in pelagic fish populations off Peru. Fish Fisher. 5, 296-316. doi: 10.1111/j.1467-2679.2004.00165.x

Biggs, R., Raudsepp-Hearne, C., Atkinson-Palombo, C., Bohensky, E., Boyd, E., Cundill, G., et al. (2007). Linking futures across scales: a dialog on multiscale scenarios. Ecol. Soc. 12:17. doi: 10.5751/ES-02051-120117

Bivand, R. S., Pebesma, E., and Gomez-Rubio, V. (2013). Applied Spatial Data Analysis with R, 2nd Edn. New York, NY: Springer. doi: 10.1007/978-1-46147618-4

Blancas, A. N. I., La Torre, M. D. L. Á, and Carrera, G. A. M. (2018). Using foresight to gain a local perspective on the future of ecosystem services in a mountain protected area in Peru. Mountain Res. Dev. 38, 192-202. doi: 10.1659/MRDJOURNAL-D-17-00090.1

Blythe, J., Silver, J., Evans, L., Armitage, D., Bennett, N. J., Moore, M. L., et al. (2018). The dark side of transformation: latent risks in contemporary sustainability discourse. Antipode 50, 1206-1223. doi: 10.1111/anti.12405
Also, special thanks to our colleagues from the project for this. Finally, thanks to all the fishers attending the FGD for their commitment and valuable help in its organization.

\section{SUPPLEMENTARY MATERIAL}

The Supplementary Material for this article can be found online at: https://www.frontiersin.org/articles/10.3389/fmars. 2020.557181/full\#supplementary-material

Börjeson, L., Höjer, M., Dreborg, K. H., Ekvall, T., and Finnveden, G. (2006). Scenario types and techniques: towards a user's guide. Futures 38, 723-739. doi: 10.1016/j.futures.2005.12.002

Bremer, S., and Funtowicz, S. (2015). Negotiating a place for sustainability science: narratives from the waikaraka estuary in New Zealand. Environ. Sci. Pol. 53, 47-59. doi: 10.1016/j.envsci.2014.11.006

Brownrigg, R. (2018). Maps: Draw Geographical Maps. R package Version 3.3.0.

Butler, J. R. A., Suadnya, W., Puspadi, K., Sutaryono, Y., Wise, R. M., Skewes, T. D., et al. (2014). Framing the application of adaptation pathways for rural livelihoods and global change in eastern Indonesian islands. Global Environ. Change 28, 368-382. doi: 10.1016/j.gloenvcha.2013. 12.004

Castillo, G., Fernández, J., Medina, A., and Guevara-Carrasco, R. (2018). Tercera encuesta estructural de la pesquería artesanal en el litoral peruano. Resultados generales. Informe Instituto del Mar del Perú 45:390. Available online at: http://biblioimarpe.imarpe.gob.pe/handle/123456789/3300? mode= full (accessed October 8, 2020).

Centro Nacional de Planeamiento Estratégico [Ceplan] (2014). National Center for Strategic Planning. XI propsecta 2014: Seminario Internacional de Prospectiva y Estudios de Futuro. Available online at: https://www.ceplan.gob.pe/portfolio/ xi-prospecta-2014-seminario-internacional-de-prospectiva- $y$-estudios-defuturo/ (accessed April 1, 2020).

Centro Nacional de Planeamiento Estratégico [Ceplan] (2019). National Center for Strategic Planning: Escenarios Contextuales. Cambios globales $y$ sus consecuencias para el Perú. Available online at: https://www.ceplan. gob.pe/documentos_/escenarios-contextuales-cambios-globales- $y$-susconsecuencias-para-el-peru-2/ (accessed April 1, 2020).

Chermack, T. J. (2011). Scenario Planning in Organizations: How to Create, use, and Assess Scenarios. San Francisco, CA: Berrett-Koehler Publishers.

Cheung, W. W., Dunne, J., Sarmiento, J. L., and Pauly, D. (2011). Integrating ecophysiology and plankton dynamics into projected maximum fisheries catch potential under climate change in the Northeast Atlantic. ICES J. Mar. Sci. 68, 1008-1018. doi: 10.1093/icesjms/fsr012

Collins, M., An, S. I., Cai, W., Ganachaud, A., Guilyardi, E., Jin, F. F., et al. (2010). The impact of global warming on the tropical Pacific Ocean and El Niño. Nat. Geosci. 3, 391-397. doi: 10.1038/ngeo868

Comisión de Promoción del Perú para la Exportación y el Turismo [PROMPERÚ] (2017). El vacacionista extranjero en el Perú - actividades culturales 2017. Available online at: https://www.promperu.gob.pe/TurismoIN//sitio/ VisorDocumentos?titulo=Vacacionista $\% 20$ extranjero $\% 20$ cultural $\% 20 \mathrm{en} \%$ 20el\%20Per\%C3\%BA\%20-\%20Actividades\%20culturales\&url=/Uploads/ infografias/1054/VacacionistaExtranjeroCulturalPeru2017.pdf\&nombObjeto= Infograf\%C3\%ADas\&back=/TurismoIN/sitio/Infografias\&issuuid=0 (accessed April 16, 2020).

Ebi, K. L., Hallegatte, S., Kram, T., Arnell, N. W., Carter, T. R., Edmonds, J., et al. (2014). A new scenario framework for climate change research: background, process, and future directions. Climatic Change 122, 363-372. doi: 10.1007/ s10584-013-0912-913

Evans, K., Murphy, L., and de Jong, W. (2014). Global versus local narratives of REDD: a case study from Peru's Amazon. Environ. Sci. Pol. 35, 98-108. doi: 10.1016/j.envsci.2012.12.013

Fasullo, J. T., Otto-Bliesner, B. L., and Stevenson, S. (2018). ENSO's changing influence on temperature, precipitation, and wildfire in a warming climate. Geophys. Res. Lett. 45, 9216-9225. doi: 10.1029/2018GL079022 
Fernández-Llamazares, Á, and Virtanen, P. K. (2020). Game masters and amazonian indigenous views on sustainability. Curr. Opin. Environ. Sustainabil. 43, 21-27. doi: 10.1016/j.cosust.2020.01.004

Food, and Agriculture Organization of the United Nations [FAO] (1999). FAO Technical Guidelines for Responsible Fisheries. No. 8. Rome: FAO.

Food and Agriculture Organization of the United Nations [FAO] (2018). The State of World Fisheries and Aquaculture 2018 - Meeting the Sustainable Development Goals. Rome: FAO Fisheries and Aquaculture Department.

Ford, A., Barr, S., Dawson, R., Virgo, J., Batty, M., and Hall, J. (2019). A multiscale urban integrated assessment framework for climate change studies: a flooding application. Comp., Environ. Urban Systems 75, 229-243. doi: 10.1016/ j.compenvurbsys.2019.02.005

Galafassi, D., Daw, T. M., Thyresson, M., Rosendo, S., Chaigneau, T., Bandeira, S., et al. (2018). Stories in social-ecological knowledge cocreation. Ecol. Soc. 23:23. doi: 10.5751/ES-09932-230123

Garnier, S. (2018). Viridis: Default Color Maps from 'Matplotlib'. R package version 0.5.1. https://CRAN.R-project.org/package=viridis.

Gonzalez, R. M. (2009). The political ecology of scallop (Argopecten purpuratus) use and management in the Pisco-Paracas region, southern Peruvian coast. Thesis, Manoa: Hawái.dissertationthesis

Guevara-Carrasco, R., and Bertrand, A. (eds) (2017). Atlas de la pesca artesanal del mar del Perú. Edición IMARPE-IRD. Available online at: http://biblioimarpe. imarpe.gob.pe/handle/123456789/3167.

Hajer, M. (1995). The Politics of Environmental Discourse Ecological Modernization and the Policy Process. Oxford: Clarendon Press.

Hamann, M., Masterson, V., Biggs, R., Tengö, M., Reyers, B., Dziba, L., et al. (2012). Social-ecological scenarios for the Eastern Cape Province. South Africa 2012-2050. Sweden: Stockholm Resilience Centre.

Hemmerling, S. A., Barra, M., Bienn, H. C., Baustian, M. M., Jung, H., Meselhe, E., et al. (2019). Elevating local knowledge through participatory modeling: active community engagement in restoration planning in coastal Louisiana. J. Geograph. Systems 22, 1-26. doi: 10.1007/s10109-019-00313-2

Instituto Nacional de Recursos Naturales [INRENA] (2008). National Institute of Natural Resources. Escenarios y Estrtegias para el manejo sostenible de los recursos naturales del Perú al 2030. Lima: INRENA.

Intergovernmental Panel on Climate Change [IPCC] (2014). AR 5 Climate Change 2014: $C$ and Vulnerabilty. Available online at: https://www.ipcc.ch/report/ar5/ wg2/ (accessed April 1, 2020).

Intergovernmental Science-Policy Platform on Biodiversity and Ecosystem Services [IPBES] (2015). Scoping Report for a Global Assessment on Biodiversity and Ecosystem Services (Deliverable 2c). Available online at: https://www.ipbes. net/sites/default/files/downloads/IPBES-4-8_EN.pdf (accessed March 6, 2020).

Karner, K., Cord, A. F., Hagemann, N., Hernandez-Mora, N., Holzkämper, A., Jeangros, B., et al. (2019). Developing stakeholder-driven scenarios on land sharing and land sparing-Insights from five European case studies. J. Environ. Manag. 241, 488-500. doi: 10.1016/j.jenvman.2019.03.050

Kebede, A. S., Nicholls, R. J., Allan, A., Arto, I., Cazcarro, I., Fernandes, J. A., et al. (2018). Applying the global RCP-SSP-SPA scenario framework at sub-national scale: a multi-scale and participatory scenario approach. Sci. Total Environ. 635, 659-672. doi: 10.1016/j.scitotenv.2018.03.368

Kluger, L. C., Kochalski, S., Aguirre-Velarde, A., Vivar, I., and Wolff, M. (2018). Coping with abrupt environmental change: the impact of the coastal El Niño 2017 on artisanal fisheries and mariculture in north peru. ICES J. Mar. Sci. 76, 1122-1130. doi: 10.1093/icesjms/fsy171

Kok, K., Pedde, S., Gramberger, M., Harrison, P. A., and Holman, I. P. (2019). New European socio-economic scenarios for climate change research: operationalising concepts to extend the shared socio-economic pathways. Reg. Environ. Change 19, 643-654. doi: 10.1007/s10113-018-1400-0

Larsen, K., and Gunnarsson-Östling, U. (2009). Climate change scenarios and citizen-participation: mitigation and adaptation perspectives in constructing sustainable futures. Habitat Int. 33, 260-266. doi: 10.1016/j.habitatint.2008. 10.00

L'Heureux, L. (2018). Exploring ENSO in Ecuador. NOAA ENSO Blog, Published 2018-11-20. Available online at: https://www.climate.gov/news-features/blogs/ enso/exploring-enso-ecuador (accessed March 30, 2020).

LimeSurvey Project Team / Carsten Schmitz (2012). LimeSurvey: An Open Source survey tool. Available online at: http://www.limesurvey.org
Maury, O., Campling, L., Arrizabalaga, H., Aumont, O., Bopp, L., Merino, G., et al. (2017). From shared socio-economic pathways (SSPs) to oceanic system pathways (OSPs): building policy-relevant scenarios for global oceanic ecosystems and fisheries. Global Environ. Change 45, 203-216. doi: 10.1016/j. gloenvcha.2017.06

McNamara, K. E., and Buggy, L. (2017). Community-based climate change adaptation: a review of academic literature. Local Environ. 22, 443-460. doi: 10.1080/13549839.2016.1216954

Meadows, D. L., Meadows, D. H., and Zahn, E. (1972). Die Grenzen des Wachstums. Bericht des Club of Rome zur Lage der Menschheit. Munich: Deutsche VerlagsAnstalt.

Meltzoff, S. K., Lemons, M., Asfour, L., Guardia-Montoya, G., and Gonzales, R. (2005). Sustaining El Niño-Induced scallop booms with aquaculture: livelihood transitions of artisanal fishing people in the paracas national reserve. Peru. Cult. Agricul. 27, 1-15. doi: 10.1525/cag.2005.27.1.1

Mendo, J., and Wosnitza-Mendo, C. (2014). Reconstruction of Total Marine Fisheries Catches for Peru: 1950-2010. Vancouver: Fisheries Centre. University of British Columbia, 23. Fisheries Centre Working Paper \#2014-21.

Millennium Ecosystem Assessment [MA] (2005). Ecosystems, and Human Wellbeing: A Framework for Assessment. Washington, DC: Island Press.

Ministerio de Agricultura y riego [MINAGRI] (2018). Anuario Estadístico de Producción Agricultura 2017. Available online at: http://siea.minagri.gob. pe/siea/sites/default/files/anuario-produccion-agricola-2017_171218_0.pdf (accessed April 16, 2020).

Ministerio de Comercio Exterior y Turismo [MINCETUR] (2019). Movimiento turístico en Ica - Año de evaluación 2018. Available online at: https:/www.mincetur.gob.pe/wp-content/uploads/documentos/turismo/ estadisticas/ReporteTurismoRegional/RTR_Ica.pdf (accessed April 16, 2020).

Ministerio de la Producción [PRODUCE] (2018). Anuario Estadístico Pesquero y Acuícola 2017 - La actividad productiva del sector en números. 205p. Available online at: http://ogeiee.produce.gob.pe/images/Anuario/Pesca_2017. pdf (accessed April 4, 2020).

Minkkinen, M. (2020). Theories in futures studies: examining the theory base of the futures field in light of survey results. World Fut. Rev. 12, 12-25. doi: $10.1177 / 1946756719887717$

Mitter, H., Techen, A. K., Sinabell, F., Helming, K., Kok, K., Priess, J. A., et al. (2019). A protocol to develop Shared Socio-economic pathways for European agriculture. J. Environ. Manag. 252:109701. doi: 10.1016/j.jenvman. 2019.109701

Moore, M. L., Tjornbo, O., Enfors, E., Knapp, C., Hodbod, J., Baggio, J. A., et al. (2014). Studying the complexity of change: toward an analytical framework for understanding deliberate social-ecological transformations. Ecol. Soc. 19:54. doi: 10.5751/ES-06966-190454

Narayan, N., Paul, A., Mulitza, S., and Schulz, M. (2010). Ocean Trends in coastal upwelling intensity during the late 20th century. Ocean Sci. 6, 815-823. doi: 10.5194/os-6-815-2010

National Marine Policy (2019). D.S 012-2019-DE. Available online at: https: //busquedas.elperuano.pe/normaslegales/decreto-supremo-que-aprueba-lapolitica-nacional-maritima-20-decreto-supremo-n-012-2019-de-1839591-1/ (accessed April 2, 2020).

Nayak, P. K., and Berkes, F. (2014). Linking global drivers with local and regional change: a social-ecological system approach in Chilika Lagoon. Bay of Bengal. Reg. Environ. Change 14, 2067-2078. doi: 10.1007/s10113-012-0369-3

Neuwirth, E. (2014). RColorBrewer: ColorBrewer Palettes. R package version 1.1-2. https://CRAN.R-project.org/package=RColorBrewer.

Nilsson, A. E., Bay-Larsen, I., Carlsen, H., van Oort, B., Bjørkan, M., Jylhä, K., et al. (2017). Towards extended shared socioeconomic pathways: a combined participatory bottom-up and top-down methodology with results from the Barents region. Global Environ. Change 45, 124-132. doi: 10.1016/j.gloenvcha. 2017.06.001

Ñiquen, M., Bouchon, M., Cahuin, S., and Valdez, J. (1999). Efectos del Fenómeno". El Niño 1997-98" sobre los principales recursos pelágicos en la costa Perúana. Revista Peruana de Biología 6, 85-96. doi: 10.15381/rpb.v6i3. 8434

Obermeister, N. (2019). Local knowledge, global ambitions: IPBES and the advent of multi-scale models and scenarios. Sustainabil. Sci. 14, 843-856. doi: 10.1007/ s11625-018-0616-8 
Oteros-Rozas, E., Martín-López, B., Daw, T. M., Bohensky, E. L., Butler, J. R., Hill, R., et al. (2015). Participatory scenario planning in place-based socialecological research: insights and experiences from 23 case studies. Ecol. Soc. 20:32. doi: 10.5751/ES-07985-200432

Palomo, I., Martín-López, B., López-Santiago, C., and Montes, C. (2011). Participatory scenario planning for protected areas management under the ecosystem services framework: the Doñana social-ecological system in southwestern Spain. Ecol. Soc. 16:23. doi: 10.5751/ES-03862-160123

Pebesma, E. (2018). simple features for r: standardized support for spatial vector data. $R$ J. 10, 439-446. doi: 10.32614/RJ-2018-009

Pebesma, E. J., and Bivand, R. S. (2005). Classes and methods for spatial data in R. R News 5, 9-13.

Pereira, L., Sitas, N., Ravera, F., Jimenez-Aceituno, A., and Merrie, A. (2019). Building capacities for transformative change towards sustainability: imagination in intergovernmental science-policy scenario processes. Elementa: Sci. Anthropocene 7:35. doi: 10.1525/elementa.374

Planque, B., Mullon, C., Arneberg, P., Eide, A., Fromentin, J. M., Heymans, J. J., et al. (2019). A participatory scenario method to explore the future of marine social-ecological systems. Fish Fish. 20, 434-451. doi: 10.1111/faf. 12356

Priess, J. A., Hauck, J., Haines-Young, R., Alkemade, R., Mandryk, M., Veerkamp, C., et al. (2018). New EU-scale environmental scenarios until 2050-Scenario process and initial scenario applications. Ecosys. Serv. 29, 542-551. doi: 10.1016/ j.ecoser.2017.08.006

R Core Team (2019). R: A Language and Environment for Statistical Computing. Vienna: R Foundation for Statistical Computing. Available online at: https: //www.R-project.org/

Rosenberg, M., Syrbe, R. U., Vowinckel, J., and Walz, U. (2014). Scenario methodology for modelling of future landscape developments as basis for assessing ecosystem services. Landscape Online 33, 1-20. doi: 10.3097/LO. 201433

Rottenburg, R. (2009). Far-Fetched Facts: A Parable of Development Aid. Cambridge, MA: MIT Press. doi: 10.7551/mitpress/9780262182645.001.0001

Saito, O., Kamiyama, C., Hashimoto, S., Matsui, T., Shoyama, K., Kabaya, K., et al. (2019). Co-design of national-scale future scenarios in Japan to predict and assess natural capital and ecosystem services. Sustainabil. Sci. 14, 5-21. doi: 10.1007/s11625-018-0587-9

Servicio Nacional de Áreas Naturales Protegidas (Sernanp). (2020). Las áreas naturales protegidas del Perú más visitadas. Available online at: https://www.promperu.gob.pe/TurismoIN//sitio/VisorDocumentos?titulo= \%C3\%81reas\%20Naturales\%20Protegidas\%20del\%20Per\%C3\%BA\%20m\% C3\%A1s\%20visitadas\%20en\%20el\%202018\&url=/Uploads/infografias/1071/ 026ANPsm\%C3\%A1svisitadas2018.pdf\&nombObjeto=Infograf\%C3\%ADas\& back=/TurismoIN/sitio/Infografias\&issuuid=0 (accessed April 16, 2020).

Taylor, M. H., Wolff, M., Mendo, J., and Yamashiro, C. (2008). Changes in trophic flow structure of Independence Bay (Peru) over an ENSO cycle. Prog. Oceanography 79, 336-351. doi: 10.1016/j.pocean.2008.10.006

Tompkins, E. L., Few, R., and Brown, K. (2008). Scenario-based stakeholder engagement: incorporating stakeholders preferences into coastal planning for climate change. J. Environ. Manag. 88, 1580-1592. doi: 10.1016/j.jenvman.2007. 07.025

Vecchi, G. A., and Wittenberg, A. T. (2010). El Niño and our future climate: where do we stand? Wiley Int. Rev. Climate Change 1, 260-270. doi: 10.1002/wcc.33

Venturini, G., Hansen, M., and Andersen, P. D. (2019). Linking narratives and energy system modelling in transport scenarios: a participatory perspective from Denmark. Energy Res. Soc. Sci. 52, 204-220. doi: 10.1016/j.erss.2019.01. 019

Voinov, A., Jenni, K., Gray, S., Kolagani, N., Glynn, P. D., Bommel, P., et al. (2018). Tools and methods in participatory modeling: selecting the right tool for the job. Environ. Modell. Softw. 109, 232-255. doi: 10.1016/j.envsoft.2018.08.028

Wickham, H. (2016). ggplot2: Elegant Graphics for Data Analysis. New York, NY: Springer-Verlag. doi: 10.1007/978-3-319-24277-4

Wickham, H., François, R., Henry, L., and Müller, K. (2019). dplyr: A Grammar of Data Manipulation. R package version 0.8.1. https:/CRAN.R-project.org/ package $=$ dplyr.

Wilke, C. O. (2019). cowplot: Streamlined Plot Theme and Plot Annotations for 'ggplot2'. R package version 0.9.4. https://CRAN.R-project.org/package= cowplot.

Wolff, M. (1984). Early setback for scallop culture in Peru. ICLARM Newsletter 19-20. Available online at: https://digitalarchive.worldfishcenter.org/bitstream/ handle/20.500.12348/3451/in_3326.pdf?sequence=1\&isAllowed=y (accessed March 30, 2020).

Wolff, M., Taylor, M. H., Mendo, J., and Yamashiro, C. (2007). A catch forecast model for the Peruvian scallop (Argopecten purpuratus) based on estimators of spawning stock and settlement rate. Ecol. Modell. 209, 333-341. doi: 10.1016/j. ecolmodel.2007.07.013

Wollenberg, E., Edmunds, D., and Buck, L. (2000). Using scenarios to make decisions about the future: anticipatory learning for the adaptive comanagement of community forests. Landscape Urban Plann. 47, 65-77. doi: 10.1016/S0169-2046(99)00071-7

Xiu, P., Chai, F., Curchitser, E. N., and Castruccio, F. S. (2018). Future changes in coastal upwelling ecosystems with global warming: the case of the California current system. Sci. Rep. 8:2866. doi: 10.1038/s41598-018-21247-7

Yung, L., Louder, L., Gallagher, L., Jones, K., and Wyborn, C. (2019). How methods for navigating uncertainty connect science and policy at the water-energy-food nexus. Front. Environ. Sci. 7:37. doi: 10.3389/fenvs.2019.00037

Conflict of Interest: The authors declare that the research was conducted in the absence of any commercial or financial relationships that could be construed as a potential conflict of interest.

Copyright (c) 2020 Garteizgogeascoa, Kluger, Gonzales, Damonte and Flitner. This is an open-access article distributed under the terms of the Creative Commons Attribution License (CC BY). The use, distribution or reproduction in other forums is permitted, provided the original author(s) and the copyright owner(s) are credited and that the original publication in this journal is cited, in accordance with accepted academic practice. No use, distribution or reproduction is permitted which does not comply with these terms. 